\title{
The Coming Age of Flavonoids in the Treatment of Diabetic Complications
}

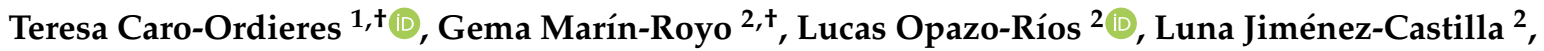 \\ Juan Antonio Moreno ${ }^{3,4,5}$, Carmen Gómez-Guerrero ${ }^{2, \ddagger}$ and Jesús Egido $2, *, \ddagger$ \\ 1 Research Discovery and Innovation Department, FAES FARMA, S.A, Department of Physiology, Faculty of \\ Medicine and Nursing, University of the Basque Country, 48940 Leioa (Bizkaia), Spain; tcaro@faes.es \\ 2 Renal, Vascular and Diabetes Research Laboratory, IIS-Fundación Jiménez Díaz, Universidad Autonoma de \\ Madrid, Spanish Biomedical Research Centre in Diabetes and Associated Metabolic Disorders (CIBERDEM), \\ 28040 Madrid, Spain; gmarinroyo@gmail.com (G.M.-R.); lucasopazo78@gmail.com (L.O.-R.); \\ luna.jimenez@quironsalud.es (L.J.-C.); Cgomez@fjd.es (C.G.-G.) \\ 3 Department of Cell Biology, Physiology and Immunology, University of Córdoba, 14004 Córdoba, Spain; \\ juanmorenoguti@gmail.com \\ 4 Maimonides Biomedical Research Institute of Cordoba (IMIBIC), University of Córdoba, \\ 14004 Córdoba, Spain \\ 5 Hospital Universitario Reina Sofía, 14004 Córdoba, Spain \\ * Correspondence: JEgido@quironsalud.es \\ + Equal contribution of first authors. \\ $\ddagger$ Equal contribution of senior authors.
}

Received: 23 December 2019; Accepted: 22 January 2020; Published: 27 January 2020

\begin{abstract}
Diabetes mellitus (DM), and its micro and macrovascular complications, is one of the biggest challenges for world public health. Despite overall improvement in prevention, diagnosis and treatment, its incidence is expected to continue increasing over the next years. Nowadays, finding therapies to prevent or retard the progression of diabetic complications remains an unmet need due to the complexity of mechanisms involved, which include inflammation, oxidative stress and angiogenesis, among others. Flavonoids are natural antioxidant compounds that have been shown to possess anti-diabetic properties. Moreover, increasing scientific evidence has demonstrated their potential anti-inflammatory and anti-oxidant effects. Consequently, the use of these compounds as anti-diabetic drugs has generated growing interest, as is reflected in the numerous in vitro and in vivo studies related to this field. Therefore, the aim of this review is to assess the recent pre-clinical and clinical research about the potential effect of flavonoids in the amelioration of diabetic complications. In brief, we provide updated information concerning the discrepancy between the numerous experimental studies supporting the efficacy of flavonoids on diabetic complications and the lack of appropriate and well-designed clinical trials. Due to the well-described beneficial effects on different mechanisms involved in diabetic complications, the excellent tolerability and low cost, future randomized controlled studies with compounds that have adequate bioavailability should be evaluated as add-on therapy on well-established anti-diabetic drugs.
\end{abstract}

Keywords: flavonoids; diabetes; microvascular complications; cardiovascular disease; diabetic nephropathy; oxidative stress; inflammation; therapeutics

\section{Introduction}

Diabetes mellitus (DM) is currently one of the greatest public health challenges in the world. Despite the new tools of control and prevention for early diagnosis, its prevalence is still increasing. Successive reports generated by the International Diabetes Federation have shown the increasing 
incidence of people with DM (actually 463 million adults) and the estimated projection for the year 2045 will rise to 700 million people affected [1].

It has been estimated that one out of every two individuals with DM is not aware of having the disease. This is particularly important in patients with type 2 diabetes (T2D) due to the long asymptomatic phase, which increases the risk of microvascular and macrovascular complications, the risk of death compared with normoglycemic individuals, and the tremendous economic cost for the health system [1-4]

The incidence of diabetes-related complications has declined substantially in the past decades worldwide probably due to a substantial improvement in preventive care programs for adults with diabetes and the extensive use of drugs controlling blood glucose, hypertension and dyslipidemia, among others [5]. However, a large burden of disease persists because of the continued increase in the prevalence of diabetes, mainly due to the threats of increasing obesity, world overpopulation and aging $[6,7]$.

Although the recent availability of novel anti-diabetic drugs (e.g., incretin modulators and sodium-glucose transport protein-2 inhibitors) will certainly further decrease the rates of cardiovascular risk and mortality in diabetic patients, the research for new drugs to halt the progression of diabetic complications is still necessary [8-11]. Due to the complexity of the pathogenic mechanisms driving long-term complications of diabetes, including inflammation and oxidative stress, the clinical introduction of novel drugs combating those conditions would be of interest [12].

In this review, we have focused on the potential beneficial effects of flavonoids on different mechanisms involved in diabetic complication, as well as the current state of research related to the preclinical and clinical usefulness of these compounds in this clinical condition. On the whole, we provide information supporting the future development of well-designed clinical trials with flavonoids that have adequate bioavailability as add-on therapy on well-established anti-diabetic drugs.

\section{Pathogenesis of Diabetic Complications}

DM is associated with several chronic complications, mainly classified as macrovascular and microvascular complications. Among them, coronary artery disease, peripheral arterial disease and stroke are described as macrovascular complications, due to a close relationship with atherosclerotic mechanisms. On the other hand, diabetic microangiopathies or microvascular complications are described at the ocular (retinopathy), renal (nephropathy) and peripheral nerve (neuropathy) levels, and are characterized by changes in the thickness of the capillary basement membrane [13,14].

In the genesis of the diabetic complications, hyperglycemia is the driving force for clinical features, which in synergy with other risk factors (hypertension, obesity, dyslipidemia) potentiates and accelerates the histopathological features classically observed in each of the tissue-specific manifestations of the DM $[15,16]$. Simultaneously, as a consequence of hyperglycemia, alterations in signaling and glucose metabolism are observed, promoting insulin resistance in target organs and beta cell dysfunction [17].

The influence of the genetic background as an individual risk factor is not only important in type 1 diabetes (T1D), but rather in all tissue-specific manifestations of DM [18]. The analyses of multicenter population genetic studies and genome-wide association studies (GWASs) have reported certain risk polymorphisms (single-nucleotide polymorphisms-SNPs) that could be involved in the diverse pathogenesis of complications associated with DM [19]. The proposed actions for these SNPs are related to phagocytosis, cytoskeleton rearrangement, fibroblast migration and lymphocyte infiltration [20]. Other studies have suggested the influence of gene alterations associated with transport and glucose metabolism, the renin angiotensin aldosterone system (RAAS), transcription factors and growth factors [21,22].

The maintenance of a hyperglycemic state involves the anabolic-catabolic production of toxic metabolites, which activate metabolic and hemodynamic pathways through the formation of advanced glycation end products (AGEs), activation of protein kinase C (PKC) and polyol sorbitol pathway, activation of RAAS, vascular endothelial growth factor A (VEGFA) and endothelin-1 and receptor type 
A (ET1/ETA). These processes cause remodeling in the architecture of the different target organs and ultimately atrophic changes [23-26]. On the other hand, the presence of oxidative stress and altered redox homeostasis in resident cells are characteristics commonly observed in DM patients [27-29]. Uncoupling endothelial nitric oxide synthase (eNOS) and the bioavailability of nitric oxide (NO) are two main factors responsible for the changes of vascular reactivity and production of reactive oxygen and nitrogen species (ROS/RNS) [30-32]. Additionally, dysregulation between pro-oxidant enzymes (e.g., NADPH oxidase complex (Nox), xanthine oxidase, cytochrome 450 and myeloperoxidase) and antioxidant enzymes (e.g., superoxide dismutase, glutathione peroxidase and catalase) is a major contributor to redox imbalance [33-35].

Kinases and transcription factors involved in many inflammatory and oxidative stress responses, activate intracellular signaling pathways that lead to the production of pro-inflammatory, pro-oxidant and pro-angiogenic factors such as cytokines, chemokines, pro-oxidant enzymes, growth factors, adhesion molecules and extracellular matrix proteins, among others [36-40].

Chronic hyperglycemia is the main pathogenic factor involved in DM complications, mainly triggering systemic and local microinflammation and therefore an important therapeutic target to hamper the development and progression of diabetic complications [41].

\section{General Aspects of Flavonoids}

Flavonoids are an important class of natural products; more precisely, flavonoids are one of the largest groups of plant secondary metabolites, comprising at least 6000 phenolic compounds. They are widely found in fruits, vegetables, nuts, grain seeds, cocoa, chocolate, tea, soy, red wine, herbs and beverage products [42-45].

Flavonoids share a common chemical structure (Figure 1A) based on a C6-C3-C6 skeleton, where two aromatic rings are linked by a three-carbon chain that forms an oxygenated heterocyclic ring [42-44]. Depending on the degree of unsaturation and the substitution pattern, different flavonoid classes can be distinguished (Figure 1B): flavones, flavonols, flavanones, flavan-3-ols, anthocyanins, dihydroflavonols, and isoflavones, as well as the biogenetic intermediate chalconoid forms [43].

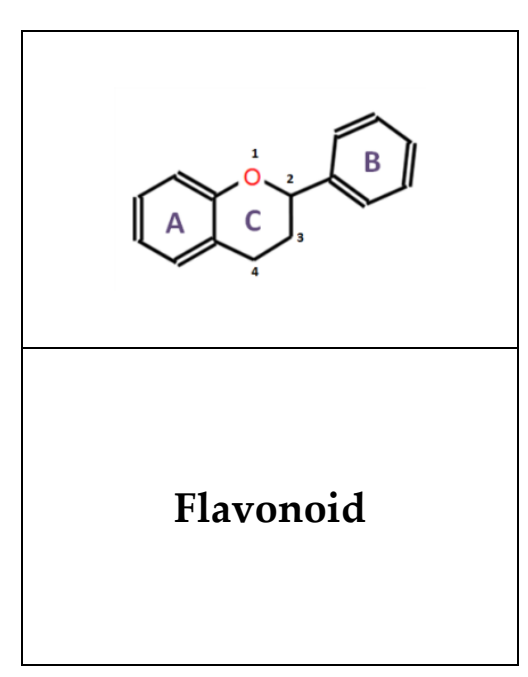

(A)

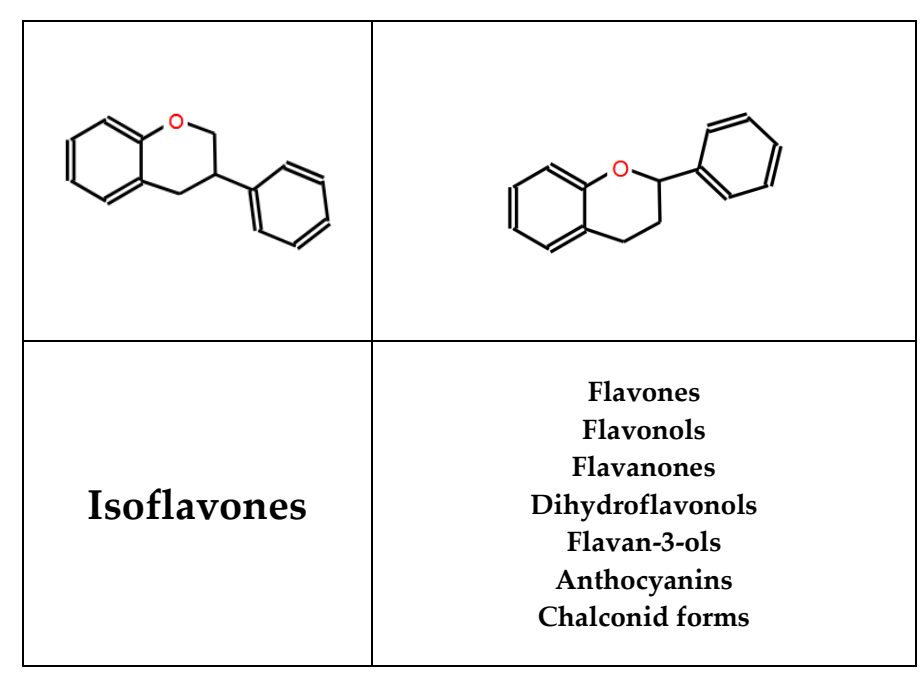

(B)

Figure 1. (A) Common chemical structure of flavonoids. (B) Chemical structure of flavonoid subtypes described in the literature.

Flavonoids have long been used in traditional medicine mainly due to their antioxidant properties; for example, Radix Puerariae (Puerarin) has been used to treat diabetes for thousands of years. Flavonoids are associated with a broad spectrum of health-promoting effects because of their anti-oxidative, anti-inflammatory and anti-carcinogenic properties and their capacity to modulate key cellular enzyme 
functions [46]. Nowadays, flavonoids are present in the pharmaceutical market in different formats such as tablets, hard capsules, granules, oral solutions and gel. The main commercialized flavonoids (Diosmin, Hesperidin, Troxerutin and Hidrosmin) are mostly used for the treatment of edema and venous insufficiency [47].

\section{Recent Preclinical Advances in the Anti-Diabetic Actions of Flavonoids}

The anti-inflammatory, anti-oxidant and anti-hyperlipidemic effects of flavonoids have been widely demonstrated. For this reason, there is much interest in these compounds as potential anti-diabetic drugs. This is reflected in the large number of in vitro and in vivo studies carried out to assess the effect of flavonoids in the context of diabetes [48-50].

Flavonoids modulate glucose metabolism or insulin sensitivity at different levels, increasing glucose uptake and insulin secretion, and inhibiting glucose production [51]. There are several publications describing the anti-diabetic action of flavonoids on different tissues such as skeletal muscle, white adipose tissue, liver, small intestine, pancreas and kidney [52]. In skeletal muscle and white adipose tissue, flavonoids mainly act on glucose transporter type 4 (GLUT4), increasing its translocation to the plasma membrane allowing the uptake of glucose from blood. The translocation of GLUT4 can be mediated by activation of different pathways such as phosphoinositide 3-kinase (PI3K)/protein kinase B (Akt) [53], and AMP-activated protein kinase (AMPK) [54]. In skeletal muscle, Yamashita et al. demonstrated that liquorice flavonoid oil promoted GLUT4 translocation by activation of the AMPK pathway and improved symptoms in T2D [54]. Sea buckthorn extract, rich in quercetin, isorhamnetin and gallic acid, also stimulated GLUT4 translocation in adipocytes and improved glucose uptake activity [53].

On the other hand, some flavonoids act by inhibiting the expression or translocation of GLUT2). In liver, Baicalin reduces GLUT2 in addition to other gluconeogenic genes, such as glucose-6-phosphatase (G6Pase) and phosphoenolpyruvate carboxykinase (PEPCK), therefore inhibiting the synthesis of glucose and its subsequent release into the bloodstream [55]. The production of hepatic glucose is also inhibited by other flavonoids such as epigallocatechin gallate, that acts by reducing the expression of PEPCK and G6Pase in hepatic (HepG2) cells $[56,57]$ and xanthohumol, that inhibits GLUT2 expression in the liver of diabetic rats [58]. The reduction of GLUT2 was noted, not only in liver but also in human intestinal cells, by the administration of anthocyanin-rich berry extract [59], myricetin, fisetin and quercetin [60].

An effective strategy to reduce increased glucose levels (in postprandial hyperglycemia, for example) is to retard the intestinal digestion of complex carbohydrates through the inhibition of $\alpha$-glucosidases. In this sense, flavonols such as rutin, quercetin and isoquercetin are considered $\alpha$-glucosidase inhibitors. The inhibition of $\alpha$-glucosidase prevents glucose absorption and consequently reduces postprandial blood glucose levels in the Sprague-Dawley rat model [61].

Another beneficial effect that flavonoids exert is the preservation of $\beta$-cell viability by reducing inflammation and oxidative damage. The capacity of guava leaf extract (containing anthocyanins and quercetin) to increase the pancreatic levels of different antioxidant enzymes such as superoxide dismutase (SOD), catalase (CAT) and glutathione peroxidase (GPx) and to downregulate the expression of inflammatory mediators, such as TNF- $\alpha$ and IL-6, in streptozotocin (STZ)-induced diabetic rats has been demonstrated [62]. Naringin also has a protective effect on $\beta$-cells due to its capacity to prevent apoptosis through the inhibition of both the intrinsic (mitochondria-mediated) and extrinsic (death receptor-mediated) pathways. These anti-apoptotic effects are associated with a reduction in ROS and inflammatory cytokines [63].

In summary, flavonoids exert their anti-diabetic effects in part by acting on different tissues (pancreas, liver, adipose tissue and skeletal muscle) involved in the modulation of glucose homeostasis and insulin sensitivity (Figure 2). 


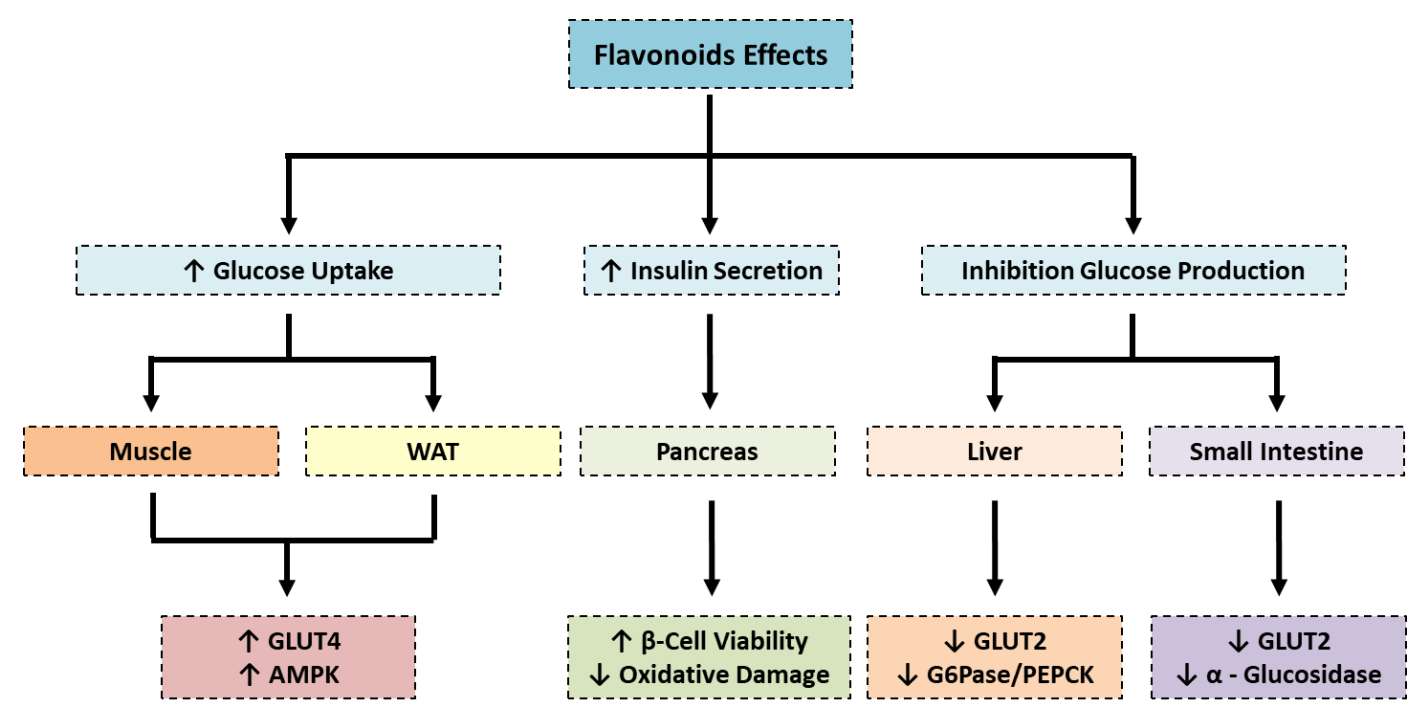

Figure 2. Effect of flavonoids on glucose metabolism. The main effect of flavonoids on skeletal muscle and adipose tissue is the enhancement of glucose uptake mediated by the translocation of GLUT4 to the plasmatic membrane. Conversely, in the liver, flavonoids act in a different way. They try to reduce glucose blood levels both by reducing gluconeogenic genes (such as G6Pase and PEPCK) and therefore glucose production and GLUT2, and therefore preventing the release of glucose from liver to the bloodstream. The production of glucose is also prevented in the intestine by blocking the digestion of complex carbohydrates. In the pancreas, flavonoids predominantly reduce oxidative stress improving the viability of $\beta$-cell, consequently ameliorating insulin secretion. WAT: White adipose tissue; AMPK: AMP-activated protein kinase; GLUT4: glucose transporter type 4, GLUT 2: glucose transporter type 2, G6Pase: glucose-6-phosphatase, PEPCK: phosphoenolypyruvate carboxykinase.

\section{Current Status of Experimental Research on Flavonoids in Chronic Complications of Diabetes}

Due to the potent antioxidant effect of flavonoids, the therapeutic potential of these compounds has been evaluated in several chronic diseases including cancer, neurodegenerative and cardiovascular disorders, and diabetes. Thus, the present review focuses on the most recent (last 3 years) preclinical studies of flavonoids for the treatment of microvascular (nephropathy, retinopathy and neuropathy) and macrovascular (cardiovascular) complications of diabetes (Table 1). 
Table 1. Effects and Mechanisms of Action of Flavonoids on Chronic Complications of DM. In vivo and in vitro Experiments.

\begin{tabular}{|c|c|c|c|c|c|c|c|}
\hline \multicolumn{8}{|c|}{ In vivo Studies } \\
\hline Disease & Animal & DM & Model & Treatment & Results & Effect & PMID \\
\hline \multirow{8}{*}{ 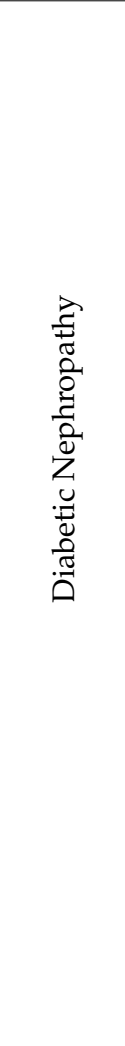 } & Rat & T1D & STZ & $\begin{array}{c}\text { Hesperidin } 100 \mathrm{mg} / \mathrm{kg} / \text { day } \\
2 \text { weeks }\end{array}$ & $\downarrow$ FGF-23; $\uparrow \alpha$-Klotho & $\begin{array}{l}\text { Anti-toxic in } \\
\text { liver/kidney }\end{array}$ & 30551370 \\
\hline & Rat & T1D & Alloxan & $\begin{array}{c}\text { Ramipril } 5 \mathrm{mg} / \mathrm{kg}+ \\
\text { Rutin } 50 \mathrm{mg} / \mathrm{kg} / \text { day } \\
6 \text { weeks }\end{array}$ & $\begin{array}{c}\text { Prevented podocyte injury, } \\
\downarrow \text { TGF- } \beta \\
\downarrow \text { GRP78 and CHOP (ER } \\
\text { stress markers) }\end{array}$ & $\begin{array}{l}\text { Anti-oxidant and } \\
\text { anti-fibrotic }\end{array}$ & 30372836 \\
\hline & Rat & T1D & STZ & $\begin{array}{l}\text { Resveratrol } 5 \mathrm{mg} / \mathrm{kg} / \text { day } \\
45 / 90 \text { days }\end{array}$ & $\begin{array}{c}\downarrow \text { Renal hypertrophy and } \\
\text { structural changes. } \downarrow \text { AGEs } \\
\text { accumulation; } \downarrow \text { oxidative } \\
\text { stress }\end{array}$ & $\begin{array}{l}\text { Renoprotective, } \\
\text { anti-fibrotic and } \\
\text { anti-oxidant }\end{array}$ & 29229234 \\
\hline & Rat & T1D & STZ & $\begin{array}{c}\text { Naringin } 20-80 \mathrm{mg} / \mathrm{kg} / \text { day } \\
12 \text { weeks }\end{array}$ & $\downarrow R O S: \uparrow S O D$ and $\downarrow$ NOX 4 & $\begin{array}{l}\text { Renoprotective and } \\
\text { anti-oxidant }\end{array}$ & 28395989 \\
\hline & Rat & $\mathrm{T} 2 \mathrm{D}$ & HFD/STZ & $\begin{array}{c}\text { Pyrrosiae folium } \\
50-200 \mathrm{mg} / \mathrm{kg} / \text { day } \\
12 \text { weeks }\end{array}$ & $\downarrow$ renal IL- 6 , TNF- $\alpha$ and IL-1 $\beta$ & $\begin{array}{l}\text { Renoprotective and } \\
\text { anti-inflammatory }\end{array}$ & 29945390 \\
\hline & Rat & $\mathrm{T} 2 \mathrm{D}$ & HFD/STZ & $\begin{array}{c}\text { Formononetin } \\
10-40 \mathrm{mg} / \mathrm{kg} / \text { day. } \\
16 \text { weeks }\end{array}$ & $\begin{array}{c}\uparrow \text { creatinine clearance; } \uparrow \text { SIRT1; } \\
\uparrow S O D ; \uparrow \text { catalase }\end{array}$ & $\begin{array}{l}\text { Renoprotective, } \\
\text { anti-diabetic and } \\
\text { anti-oxidant }\end{array}$ & 30641085 \\
\hline & Mouse & T1D & STZ & $\begin{array}{c}\text { Diosmetin } \\
25-100 \mathrm{mg} / \mathrm{kg} / \text { day } \\
8 \text { weeks }\end{array}$ & $\begin{array}{l}\text { Reduced serum FBG, BUN } \\
\text { and creatinine and } \\
\text { albuminuria. } \downarrow \text { Akt and NF-kB } \\
\text { expression. } \uparrow \text { iNOS }\end{array}$ & $\begin{array}{c}\text { Renoprotective, } \\
\text { anti-diabetic, } \\
\text { anti-inflammatory and } \\
\text { anti-oxidant }\end{array}$ & 30278036 \\
\hline & Mouse & $\mathrm{T} 2 \mathrm{D}$ & $\mathrm{db} / \mathrm{db}$ mouse & $\begin{array}{c}\text { Chrysin } 10 \mathrm{mg} / \mathrm{kg} / \text { day } \\
10 \text { weeks }\end{array}$ & $\begin{array}{c}\downarrow \text { Collagen fiber accumulation } \\
\downarrow \text { AGEs accumulation }\end{array}$ & Anti-fibrotic & 29987200 \\
\hline
\end{tabular}


Table 1. Cont

\begin{tabular}{|c|c|c|c|c|c|c|c|}
\hline \multicolumn{8}{|c|}{ In vivo Studies } \\
\hline Disease & Animal & DM & Model & Treatment & Results & Effect & PMID \\
\hline \multirow{7}{*}{ 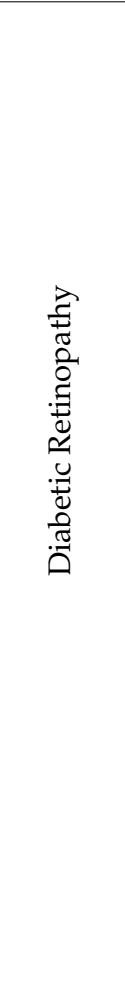 } & Rat & T1D & STZ & $\begin{array}{l}\text { Catechin } 50-200 \\
\mathrm{mg} / \mathrm{kg} / \text { day } \\
8 \text { weeks }\end{array}$ & $\begin{array}{l}\text { Modulation NF- } \kappa \text { B pathway } \\
\downarrow \downarrow \text { IL- } 1 \beta \text {, IL-6, and TNF- } \alpha\end{array}$ & Anti-inflammatory & 30373863 \\
\hline & Rat & T1D & STZ & $\begin{array}{c}\text { Biochanin A } \\
10-15 \mathrm{mg} / \mathrm{kg} / \text { day. } 6 \text { weeks }\end{array}$ & $\downarrow \mathrm{TNF} \alpha, \mathrm{IL}-1 \beta$ and VEGF & $\begin{array}{l}\text { Anti-inflammatory } \\
\text { and } \\
\text { anti-angiogenic }\end{array}$ & 30054234 \\
\hline & Rat & T1D & STZ & $\begin{array}{c}\text { Trans-Resveratrol } \\
5 \mathrm{mg} / \mathrm{kg} / \text { day. } 2-4 \text { weeks }\end{array}$ & $\begin{array}{l}\uparrow \text { Cyp26b1 and Cyp3a9 } \\
\text { transcription levels }\end{array}$ & Anti-oxidant & 30030988 \\
\hline & Rat & T1D & STZ & $\begin{array}{c}\text { Morus alba extract } \\
100 \mathrm{mg} / \mathrm{kg} / \text { day } \\
16 \text { weeks }\end{array}$ & $\begin{array}{c}\downarrow \text { Caspase- } 3 \text {, Bax and } \uparrow \text { Bcl2; } \\
\downarrow \text { TNF- } \alpha \text { and IL- } 1 \beta ; \uparrow C A T, \\
\text { SOD and GPx. } \downarrow \text { VEGF }\end{array}$ & $\begin{array}{c}\text { Anti-apoptotic, } \\
\text { anti-oxidant, } \\
\text { anti-inflammatory and } \\
\text { anti-angiogenic }\end{array}$ & 27059477 \\
\hline & Rat & T1D & STZ & $\begin{array}{c}\text { Naringenin } \\
50 \mathrm{mg} / \mathrm{kg} / \text { day } 5 \text { weeks }\end{array}$ & $\begin{array}{c}\uparrow G S H ; \downarrow \text { Caspase- } 3, \text { Bax and } \\
\uparrow \text { Bcl2; } \downarrow \text { pro-BDNF and } \\
\uparrow \text { BDNF }\end{array}$ & $\begin{array}{l}\text { Neuroprotective, } \\
\text { anti-oxidant and } \\
\text { anti-apoptotic }\end{array}$ & 29064407 \\
\hline & Mouse & T1D & STZ & $\begin{array}{l}\text { Galangin } 10 \mathrm{mg} / \mathrm{kg} / \mathrm{day} \\
30 \text { days }\end{array}$ & $\begin{array}{c}\uparrow \text { Occludin and claudin1; } \\
\downarrow \text { Iba-1 } \\
\downarrow \text { TNF } \alpha, \text { IL-1 } \beta \text { and IL-6 } \\
\downarrow \text { p65, I B B and IKK } \\
\text { phosphorylation }\end{array}$ & $\begin{array}{l}\text { Neuroprotective and } \\
\text { anti-inflammatory }\end{array}$ & 30597356 \\
\hline & Mouse & $\mathrm{T} 2 \mathrm{D}$ & $\mathrm{db} / \mathrm{db}$ mouse & $\begin{array}{c}\text { Chrysin } 10 \mathrm{mg} / \mathrm{kg} / \text { day } \\
10 \text { weeks }\end{array}$ & $\begin{array}{c}\text { Increasing retinoid binding } \\
\text { proteins (RPE65, LRAT, } \\
\text { RDH5, and rhodopsin) }\end{array}$ & Anti-oxidant & 30096827 \\
\hline
\end{tabular}


Table 1. Cont

\begin{tabular}{|c|c|c|c|c|c|c|c|}
\hline \multicolumn{8}{|c|}{ In vivo Studies } \\
\hline Disease & Animal & DM & Model & Treatment & Results & Effect & PMID \\
\hline \multirow{4}{*}{ 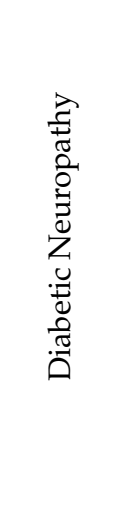 } & Rat & T1D & STZ & $\begin{array}{l}\text { Catechin } \\
\text { 25/50 mg/kg/day } \\
4 \text { weeks }\end{array}$ & $\begin{array}{c}\uparrow S O D \text { and CAT } \\
\downarrow \text { MDA and lymphocyte } \\
\text { infiltration }\end{array}$ & $\begin{array}{l}\text { Neuroprotective and } \\
\text { antioxidant }\end{array}$ & 30372853 \\
\hline & Rat & T1D & STZ & $\begin{array}{c}\text { Deguelin } 4-8 \mathrm{mg} / \mathrm{kg} / \text { day } \\
2 \text { weeks }\end{array}$ & $\begin{array}{c}\uparrow \mathrm{Nrf} 2 ; \downarrow \text { caspase- } 3 \text { in neurons } \\
\uparrow(\mathrm{Na}+-\mathrm{K}+) \text { ATPase activity }\end{array}$ & $\begin{array}{l}\text { Neuroprotective, } \\
\text { anti-oxidant and } \\
\text { anti-inflammatory }\end{array}$ & 30045011 \\
\hline & Rat & T1D & STZ & $\begin{array}{c}\text { Resveratrol } 10 \mathrm{mg} / \mathrm{kg} / \text { day } \\
120 \text { days }\end{array}$ & $\begin{array}{c}\uparrow \text { SOD and GSH; } \downarrow \text { nitrosative } \\
\text { stress } \\
\text { and MPO }\end{array}$ & $\begin{array}{l}\text { Anti-oxidant and } \\
\text { anti-inflammatory } \\
\text { effect }\end{array}$ & 29906751 \\
\hline & Rat & T1D & STZ & $\begin{array}{c}\text { Phloretin } 25-50 \mathrm{mg} / \mathrm{kg} / \text { day } \\
4 \text { weeks }\end{array}$ & $\begin{array}{c}\uparrow \text { SOD and GSH } \\
\downarrow \text { IL- } 6 \text { and TNF- } \alpha ; \downarrow \text { MDA }\end{array}$ & $\begin{array}{l}\text { Neuroprotective, } \\
\text { anti-oxidant and } \\
\text { anti-inflammatory }\end{array}$ & 29635891 \\
\hline \multirow{5}{*}{ 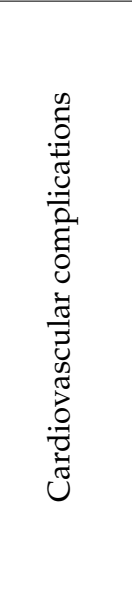 } & Rat & $\mathrm{T} 2 \mathrm{D}$ & HGI & $\begin{array}{c}\text { Rutin } 25-50 \mathrm{mg} / \mathrm{kg} / \text { day } \\
12 \text { weeks }\end{array}$ & $\begin{array}{l}\downarrow \text { inflammasome pathway in } \\
\text { aortic tissue; } \downarrow \text { ROS generation }\end{array}$ & $\begin{array}{l}\text { Anti-inflammatory } \\
\text { and anti-oxidant }\end{array}$ & 27936392 \\
\hline & Rat & $\mathrm{T} 2 \mathrm{D}$ & HFD/STZ & $\begin{array}{c}\text { Resveratrol } 10 \mathrm{mg} / \mathrm{kg} / \text { day } \\
8 \text { weeks }\end{array}$ & $\begin{array}{l}\downarrow \text { TLR4/MyD88/NF-kB } \\
\text { signaling pathway. }\end{array}$ & $\begin{array}{l}\text { Cardioprotective and } \\
\text { anti-inflammatory }\end{array}$ & 30658350 \\
\hline & Rat & T1D & STZ & $\begin{array}{c}\text { Apigenin } 100 \mathrm{mg} / \mathrm{kg} / \text { day } \\
7 \text { months }\end{array}$ & $\begin{array}{c}\downarrow \text { cardiomyocyte enlargement; } \\
\uparrow \text { SOD and GPx } \\
\downarrow \text { NF-kB/p65 signaling } \\
\text { pathway activation } \\
\downarrow \text { Col-I, Col-III, CTGF, TGF } \beta\end{array}$ & $\begin{array}{c}\text { Cardioprotective, } \\
\text { anti-oxidant, } \\
\text { anti-inflammatory and } \\
\text { anti-fibrotic }\end{array}$ & 28176247 \\
\hline & Rat & T1D & STZ + IRIA & $\begin{array}{c}\text { Resveratrol } 5 \mathrm{mg} / \mathrm{kg} / \mathrm{day}+ \\
\text { Glibenclamide } 5 \mathrm{mg} / \mathrm{kg} / \text { day } \\
6 \text { weeks }\end{array}$ & $\begin{array}{l}\uparrow \text { Kir6.2 expression (subunit } \\
\text { of } \mathrm{K}_{\text {ATP }} \text { channel) }\end{array}$ & Anti-arrhythmic & 28176247 \\
\hline & Rat & T1D & STZ & $\begin{array}{c}\text { Heracleum Persicum } \\
100 \mathrm{mg} / \mathrm{kg} / \mathrm{day} ; 8 \text { weeks }\end{array}$ & $\downarrow \mathrm{MDA} ; \uparrow \mathrm{GSH}, \mathrm{CAT}$ and SOD & Anti-oxidant & 29726706 \\
\hline
\end{tabular}


Table 1. Cont

\begin{tabular}{|c|c|c|c|c|c|c|c|}
\hline \multicolumn{8}{|c|}{ In vivo Studies } \\
\hline Disease & Animal & DM & Model & Treatment & Results & Effect & PMID \\
\hline & Rat & T1D & STZ & $\begin{array}{l}\text { Isoquecertin } 40 \mathrm{mg} / \mathrm{kg} / \text { day } \\
45 \text { days }\end{array}$ & $\downarrow \mathrm{TG}, \mathrm{PPL}$ and FFA & Anti-hyperlipidemic & 30817903 \\
\hline & Rat & T1D & STZ & $\begin{array}{c}\text { Galangin } 40 \mathrm{mg} / \mathrm{kg} \\
45 \text { days }\end{array}$ & $\begin{array}{l}\downarrow \mathrm{TG}, \mathrm{PPL} \text {, total cholesterol } \\
\text { and FFA }\end{array}$ & Anti-hyperlipidemic & 29952676 \\
\hline & Mouse & $\mathrm{T} 2 \mathrm{D}$ & $\mathrm{db} / \mathrm{db}$ mouse & $\begin{array}{c}\text { Scutellarin } 25-100 \mathrm{mg} / \mathrm{kg} \\
8 \text { weeks }\end{array}$ & $\begin{array}{c}\uparrow \text { high-density lipoprotein } \\
\text { cholesterol } \\
\downarrow \text { TG and cholesterol }\end{array}$ & Anti-hyperlipidemic & 30881587 \\
\hline & Mouse & $\mathrm{T} 2 \mathrm{D}$ & HFI & $\begin{array}{l}\text { Liquiritigenin } \\
4-16 \mathrm{mg} / \mathrm{kg} / \text { day }\end{array}$ & $\begin{array}{c}\downarrow N F-\kappa B \text { signaling pathway } \\
\downarrow \alpha \text {-SMA, Col-I, Col-II, } \\
\text { TGF- } \beta 1\end{array}$ & $\begin{array}{l}\text { Anti- inflammatory } \\
\text { and anti-fibrotic }\end{array}$ & 28039849 \\
\hline & Mouse & $\mathrm{T} 2 \mathrm{D}$ & HFI & $\begin{array}{c}\text { Liquiritin } \\
10 / 20 \mathrm{mg} / \mathrm{kg} / \text { day }\end{array}$ & $\downarrow \alpha$-SMA, Col I and Col II & Anti-fibrotic & 27810791 \\
\hline \multicolumn{8}{|c|}{ In vitro Studies } \\
\hline Disease & \multicolumn{2}{|c|}{ Cell type } & Stimulus & Treatment & Results & Effect & PMID \\
\hline \multirow{5}{*}{ 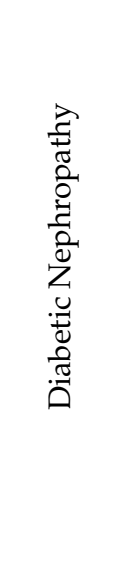 } & \multicolumn{2}{|c|}{$\begin{array}{l}\text { Human embryonic } \\
\text { kidney cells }\end{array}$} & HG & $\begin{array}{c}\text { Combretum micranthum } \\
10-25 \mu \mathrm{g} / \mathrm{mL}\end{array}$ & $\begin{array}{l}\text { Hydrogen peroxide and nitric } \\
\text { oxide scavenging activity }\end{array}$ & Anti-oxidant & 30976670 \\
\hline & \multicolumn{2}{|c|}{ Rat mesangial cells } & HG & Marein $100-400 \mu \mathrm{M}$ & $\begin{array}{c}\text { Regulating AMPK, } \\
\text { TGF- } \beta 1 / \text { Smads pathway } \\
\downarrow \text { NF- } \text { B signaling pathway }\end{array}$ & $\begin{array}{l}\text { Anti-inflammatory } \\
\text { and anti-fibrotic }\end{array}$ & 30630477 \\
\hline & \multicolumn{2}{|c|}{$\begin{array}{l}\text { Rat/human renal } \\
\text { tubular epithelial cells }\end{array}$} & HG & Kaempferol 5-50 $\mu \mathrm{M}$ & $\downarrow$ RhoA/Rho Kinase signaling & $\begin{array}{l}\text { Anti-inflammatory, } \\
\text { anti-oxidant and } \\
\text { anti-fibrotic }\end{array}$ & 30551415 \\
\hline & \multicolumn{2}{|c|}{ Mesangial cells } & HG & $\begin{array}{l}\text { Corn silk extract } \\
200 \mu \mathrm{g} / \mathrm{mL}\end{array}$ & $\begin{array}{l}\downarrow \alpha \text {-glucosidase and } \\
\alpha \text {-amylase, IL-6, AGEs, } \\
\text { Col IV and fibronectin }\end{array}$ & $\begin{array}{l}\text { Anti-inflammatory, } \\
\text { anti-oxidant and } \\
\text { anti-fibrotic }\end{array}$ & 30530231 \\
\hline & \multicolumn{2}{|c|}{ Rat mesangial cells } & AGEs & Kaempferitrin 10-35 $\mu \mathrm{M}$ & $\begin{array}{c}\uparrow S O D \text { activity } \\
\downarrow \text { MDA, Col IV and TGF- } \beta 1\end{array}$ & $\begin{array}{l}\text { Anti-oxidant and } \\
\text { anti-fibrotic }\end{array}$ & 30373106 \\
\hline
\end{tabular}


Table 1. Cont

\begin{tabular}{|c|c|c|c|c|c|c|}
\hline \multicolumn{7}{|c|}{ In vitro Studies } \\
\hline Disease & Cell type & Stimulus & Treatment & Results & Effect & PMID \\
\hline & Rat mesangial cells & HG & Liquiritigenin $20-40 \mu \mathrm{M}$ & $\begin{array}{c}\downarrow \text { NOX4 and } \uparrow \text { SOD } \\
\text { Decrease collagen IV } \\
\text { fibronectin, Il-6 and IL-1 } \beta\end{array}$ & $\begin{array}{c}\text { Anti-oxidant, } \\
\text { anti-inflammatory and } \\
\text { anti-fibrotic }\end{array}$ & 30119269 \\
\hline & $\begin{array}{l}\text { Human proximal } \\
\text { tubular epithelial cells }\end{array}$ & HG & Astilbin $10-20 \mu \mathrm{M}$ & $\begin{array}{c}\text { Modulating PI3K/Akt } \\
\text { pathway }\end{array}$ & Anti-proliferative & 30119185 \\
\hline & $\begin{array}{l}\text { Mouse podocyte cell } \\
\text { line }\end{array}$ & HG & Genistein $20 \mu \mathrm{M}$ & Inactivating mTOR signaling & Autophagia & 29999001 \\
\hline & Human mesangial cells & HG & Chrysin $1-20 \mu \mathrm{M}$ & $\begin{array}{c}\downarrow \text { Collagens, } \alpha \text {-SMA, } \\
\text { fibroblast-specific protein- } 1, \\
\text { MMPs }\end{array}$ & Anti-fibrotic & 29987200 \\
\hline & Rat mesangial cells & HG & Naringin 5-80 $\mu \mathrm{mol} / \mathrm{L}$ & $\begin{array}{c}\text { Modulating NLRP3 signaling } \\
\text { pathway } \\
\downarrow I L-1 \beta, \text { IL-18 and caspase- } 1\end{array}$ & $\begin{array}{l}\text { Anti-inflammatory } \\
\text { and anti-apoptotic }\end{array}$ & 29929501 \\
\hline & Rat mesangial cells & AGEs & Kaempferitrin 10-35 $\mu \mathrm{M}$ & $\begin{array}{c}\downarrow \text { MDA levels; } \uparrow S O D \text { and ROS } \\
\text { generation. } \downarrow \text { Collagen IV and } \\
\text { TGF- } \beta 1\end{array}$ & $\begin{array}{l}\text { Anti-oxidant and } \\
\text { anti-fibrotic }\end{array}$ & 30373106 \\
\hline & Human mesangial cells & AGEs & Chrysin $1-20 \mu \mathrm{M}$ & $\begin{array}{c}\downarrow \text { Collagens, } \alpha \text {-SMA, } \\
\text { fibroblast-specific protein-1, } \\
\text { MMPs }\end{array}$ & Anti-fibrotic & 29987200 \\
\hline \multirow{3}{*}{ 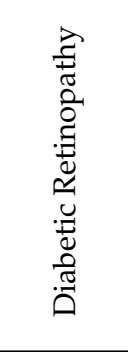 } & $\begin{array}{l}\text { Human retinal pigment } \\
\text { epithelial cell line }\end{array}$ & $\begin{array}{l}\text { Glucose } \\
\text { oxidase }\end{array}$ & Myricetin $40 \mu \mathrm{g} / \mathrm{mL}$ & $\begin{array}{c}\text { Activation of Nrf2 } \\
\uparrow \text { SOD } \downarrow \text { NOS2 }\end{array}$ & Anti-oxidant & 30820141 \\
\hline & $\begin{array}{c}\text { Human retinal pigment } \\
\text { epithelial/endothelial } \\
\text { cells }\end{array}$ & HG & Baicalin $2.5-100 \mu \mathrm{M}$ & $\begin{array}{l}\text { Inhibition of NF-KB and p38 } \\
\text { MAPK pathways }\end{array}$ & $\begin{array}{l}\text { Anti-apoptotic and } \\
\text { anti-inflammatory }\end{array}$ & 30625293 \\
\hline & $\begin{array}{l}\text { Human retinal pigment } \\
\text { epithelial cell line }\end{array}$ & $\mathrm{H}_{2} \mathrm{O}_{2}$ & Kaempferol 20-100 nM & $\begin{array}{c}\text { Modulation } \\
\text { Bax/Bcl-2/caspase-3 pathway; } \\
\uparrow \text { SOD and } \downarrow \text { VEGF }\end{array}$ & $\begin{array}{l}\text { Anti-apoptotic, } \\
\text { anti-oxidant, and } \\
\text { anti-angiogenic }\end{array}$ & 30584457 \\
\hline
\end{tabular}


Table 1. Cont

\begin{tabular}{|c|c|c|c|c|c|c|}
\hline \multicolumn{7}{|c|}{ In vitro Studies } \\
\hline Disease & Cell type & Stimulus & Treatment & Results & Effect & PMID \\
\hline & $\begin{array}{l}\text { Human retinal pigment } \\
\text { epithelium cells }\end{array}$ & HG & Chrysin $1-20 \mu \mathrm{M}$ & $\begin{array}{l}\downarrow \text { VEGF and PDGF, AGEs } \\
\text { and ER stress }\end{array}$ & Anti-angiogenic & 30096827 \\
\hline & $\begin{array}{l}\text { Human retinal capillary } \\
\text { endothelial cells }\end{array}$ & HG & $\begin{array}{l}\text { Blueberry Anthocyanin } \\
\qquad 10 \mu \mathrm{g} / \mathrm{mL}\end{array}$ & $\begin{array}{c}\uparrow C A T, \text { SOD, } \downarrow \text { Nox4 and } \\
\text { eNOS levels } \\
\downarrow \text { ICAM- } 1 \text { and NF- }-\kappa B ; \downarrow \text { VEGF }\end{array}$ & $\begin{array}{c}\text { Anti-oxidant, } \\
\text { anti-inflammatory and } \\
\text { anti-angiogenic }\end{array}$ & 29682153 \\
\hline & Rat retinal ganglial cells & HG & $\begin{array}{c}\text { Eriodictyol } \\
5-20 \mu \mathrm{M}\end{array}$ & $\begin{array}{c}\downarrow R O S \text { and } \uparrow \text { SOD, GPx, } \\
\text { catalase } \\
\downarrow \text { TNF } \alpha, \text { IL-8 }\end{array}$ & $\begin{array}{l}\text { Anti-oxidant and } \\
\text { anti-inflammatory }\end{array}$ & 30317656 \\
\hline & $\begin{array}{l}\text { Mice microglia retinal } \\
\text { cells }\end{array}$ & $\mathrm{HG}$ & $\begin{array}{l}\text { Galangin } \\
20 / 50 \mu \mathrm{M}\end{array}$ & $\begin{array}{c}\downarrow \mathrm{IL}-1 \beta, \mathrm{TNF} \alpha ; \downarrow \text { NF-kB } \\
\text { activation }\end{array}$ & Anti-inflammatory & 30597356 \\
\hline \multirow{3}{*}{ 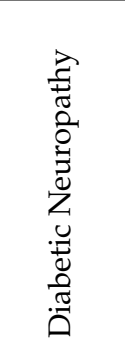 } & $\begin{array}{c}\text { Rat dorsal root ganglion } \\
\text { neurons }\end{array}$ & HG & $\begin{array}{l}\text { Quercetin } 10 \mathrm{mmol} / \mathrm{L} \\
\text { + other flavonoids }\end{array}$ & $\begin{array}{c}\uparrow \text { Nrf-2/HO- } 1 \text { pathway; } \\
\text { scavenging ROS } \\
\downarrow N F-\kappa B \text { activation }\end{array}$ & $\begin{array}{l}\text { Anti-oxidant and } \\
\text { anti-inflammatory }\end{array}$ & 28861887 \\
\hline & Schwann cells & HG & Puerarin $10 \mu \mathrm{mol} / \mathrm{L}$ & $\begin{array}{c}\downarrow \text { Caspase- } 3 ; \text { } \downarrow \text { ROS production } \\
\text { and mitochondria } \\
\text { depolarization }\end{array}$ & $\begin{array}{l}\text { Anti-apoptotic and } \\
\text { anti-oxidant }\end{array}$ & 28181078 \\
\hline & $\begin{array}{l}\text { Rat dorsal root } \\
\text { ganglion neurons }\end{array}$ & $\mathrm{HG}$ & Quercetin $2.5-10 \mathrm{mmol} / \mathrm{L}$ & $\begin{array}{c}\uparrow \text { Nrf-2/HO-1; } \downarrow \text { NF-kB } \\
\text { inhibition }\end{array}$ & $\begin{array}{l}\text { Anti-oxidant and } \\
\text { anti-inflammatory }\end{array}$ & 23770986 \\
\hline \multirow{3}{*}{ 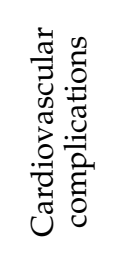 } & $\begin{array}{l}\text { Human aortic } \\
\text { endothelial cells }\end{array}$ & Palmitic acid & $\begin{array}{c}\text { Blueberry Anthocyanins } \\
12-16 \mathrm{nmol}\end{array}$ & $\begin{array}{c}\downarrow \text { Nox-mediated ROS } \\
\text { production }\end{array}$ & Anti-oxidant & 29024402 \\
\hline & $\begin{array}{c}\text { Human umbilical } \\
\text { vein endothelial cells }\end{array}$ & HG & Rutin 30-100 $\mu \mathrm{M}$ & $\downarrow$ Nox 2 and Nox4 & Anti-oxidant & 27936392 \\
\hline & $\begin{array}{l}\text { Human aortic } \\
\text { endothelial cells }\end{array}$ & Palmitic acid & Resveratrol 50-100 $\mu \mathrm{M}$ & $\begin{array}{l}\downarrow \text { ROS production via } \\
\text { AMPK-mTOR pathway }\end{array}$ & $\begin{array}{l}\text { Autophagia and } \\
\text { anti-oxidant }\end{array}$ & 30421395 \\
\hline
\end{tabular}




\subsection{Diabetic Nephropathy}

Diabetic nephropathy (DN), one of the most prevalent complications in diabetes, is characterized by a progressive development of renal dysfunction. In the early stage, the first symptom is microalbuminuria (appearance of low levels of albumin in the urine, $30-300 \mathrm{mg} / \mathrm{g}$ ), which precedes macroalbuminuria (high levels of albumin in the urine, $>300 \mathrm{mg} / \mathrm{g}$ ), leading to a deterioration of renal function and progression to End Stage Renal Disease (ESRD) [64]. Accumulating evidence has clearly demonstrated that immune-inflammatory response plays a paramount role in the onset and progression of diabetic kidney disease. This process is mediated by elements of the immune system (e.g., lymphocytes and monocytes/macrophages) and effector molecules including cytokines, growth factors, chemokines adhesion molecules, and enzymes [65]. Several in vitro and in vivo studies have evaluated the role of flavonoids on DN, most of them reporting a positive effect on renal function, evidenced by reduced levels of serum creatinine and urine albumin $[66,67]$. For example, in a rat model of STZ-induced DN combined with high-fat, high-carbohydrate diet, the treatment with mangiferin extracted from Pyrrosiae folium down-regulated IL-6, TNF- $\alpha$ and IL-1 $\beta$ expression and improved renal pathological damage [67]. Similarly, corn silk extract, liquiritigenin and naringin also exhibited anti-inflammatory activity by reducing the expression of IL-1 $\beta$ and IL-18 in mesangial cells exposed to high glucose conditions [68-70].

In diabetic kidney, high levels of glucose and other metabolites, including inflammatory cytokines and free fatty acids, lead to an excessive ROS production, being Nox and mitochondrial dysfunction the main sources of ROS generation [71]. It has been demonstrated that ROS promote serine phosphorylation of insulin receptor and insulin receptor substrate through different pathways inducing insulin signaling suppression [72]. Moreover, overproduction of ROS modulates activation of PKC, mitogen-activated protein kinases (MAPK), and several transcription factors and cytokines responsible of the inflammatory response and extracellular matrix accumulation with further progression to ESRD [71].

A number of studies have described the renal antioxidant effects of several flavonoids. Formonetin reduced oxidative stress burden and attenuated kidney damage in a T2D rat model by increasing the activity of the antioxidant enzymes SOD and CAT, along with induction of the protective molecule Sirtuin-1 [73]. Diosmetin, a flavonoid extracted from the leaves of Olea europaea with strong antioxidant property, restored the reduced levels of SOD and NO observed in the kidney of diabetic rats and decreased the levels of malondialdehyde (MDA), a lipid peroxidation marker [66]. The flavanone naringin also attenuates ROS production in diabetic kidneys with concomitant reduction in Nox4 expression and increase in antioxidant enzymes SOD and GPx [74]. In vitro experiments have also demonstrated that the strong anti-oxidant effect of different flavonoids (e.g., corn silk extracts and liquiritigenin) is linked to Nox4 inhibition and SOD induction $[68,69,75]$.

AGEs could accumulate in glomerular basement membrane, podocytes, endothelial cells and mesangial cells in diabetic patients compromising renal function through different mechanisms, such as oxidative stress, chronic inflammation and fibrosis. Therefore, the blockade of AGEs and their receptor system (RAGEs) as well as downstream related pathways has become another therapeutic target for the treatment of DN [76]. In this regard, the protective effect of kaempferitrin was evaluated in glomerular mesangial cells exposed to AGEs [75]. In this study, kaempferitrin reduced AGE-induced oxidative stress by increasing SOD activity and by reducing MDA levels and ROS generation. Moreover, this flavonoid prevented the increase in collagen IV and TGF- $\beta 1$ levels [75]. The anti-fibrotic effect has also been demonstrated by other flavonoids such as chrysin which inhibited AGEs-induced expression of collagens, and matrix metalloproteinases in mesangial cells and prevented collagen and AGEs accumulation in diabetic kidneys from the $d b / d b$ mouse model of T2D [77].

The polyphenolic natural product resveratrol though described as a non-flavonoid compound, also reduced AGE levels in kidneys, attenuating the progression of DN [78]. 


\subsection{Diabetic Retinopathy}

Diabetic retinopathy (DR) is a complication of diabetes affecting the eye that may cause severe vision loss and blindness. High glucose levels are associated with damage to the vasculature of retina. Diabetic macular edema is a consequence of DR that causes swelling in the area of the retina called the macula [79].

Several studies have assessed the potential benefits of flavonoids on eye affectation during diabetes. Most of them have shown the antioxidant, anti-inflammatory and anti-angiogenic effect exerted by flavonoids in the eye, leading to an improvement in DR. For example, catechin inactivated the NF- $\mathrm{kB}$ signaling pathway and reduced the expression of downstream target genes (e.g., IL-1 $\beta$, IL-6, and TNF- $\alpha$ ) in the retina of STZ-induced diabetic rats [80]. Biochanin A showed a dual action on inflammation and angiogenesis in a type 1 diabetic rat model, associated with decreased expression of TNF- $\alpha$, IL-1 $\beta$ and VEGF in the retina [81]. Similarly, administration of morus alba extract [82] or the flavanone naringenin [83] attenuated oxidative, apoptotic, angiogenic and neurodegenerative markers, whereas gallangin [84] attenuated inflammation and blood-retinal barrier breakdown in diabetic rats.

An in vitro study performed in human retinal capillary endothelial cells exposed to high glucose concentrations demonstrated that blueberry anthocyanin extracts reduced VEGF by inhibiting the Akt pathway. This anti-angiogenic effect was accompanied by an improvement in the oxidative and inflammatory state, evidenced by increased antioxidant enzymes (SOD and CAT) and reduced pro-oxidant enzymes (Nox4 and eNOS) and NF-kB activity [85]. Moreover, anti-inflammatory and anti-oxidant effects have also been demonstrated by myricetin, eriodyctiol and galangin in retinal epithelial, ganglial and microglial cells, respectively $[84,86,87]$. In addition, baicalin protects human retinal pigment epithelial cells against hyperglycemic conditions by reducing the proliferative, anti-apoptotic and anti-inflammatory effects by up-regulation of miR-145 and further inhibition of NF-kB and p38 MAPK pathways [88].

Kang et al. demonstrated that chrysin ameliorated the malfunction of the retinoid visual cycle by increasing retinoid binding proteins (RPE65, LRAT, RDH5, and rhodopsin), downregulating angiogenic factors, and blocking AGE-induced endoplasmic reticulum stress in glucose-stimulated RPE cells and diabetic retina of $d b / d b$ mice [89].

\subsection{Diabetic Neuropathy}

Diabetic neuropathy is a peripheral nerve disorder that affects organs which are innervated by the autonomic nervous system like heart, eyes, gastrointestinal tract, kidney, and liver. Diabetic neuropathy affects more than $50 \%$ of all diabetic patients and is commonly associated with loss of sensation in the feet leading to difficulty to walk and weakness in the foot muscles [90]. Oxidative stress and inflammation play a central role in neuronal degeneration. Oxidative stress leads to activation of inflammatory and apoptotic pathways resulting in insufficiency of neurochemical growth factors, neurovascular dysfunction, demyelination of neurons and increased autoimmune damage [91,92]. Therefore, the inhibition of oxidative stress and inflammation cascades could be an option to prevent the development of diabetic neuropathy.

Several examples of the protective actions of flavonoids against diabetic neuropathy have been published. Catechin, in a model of STZ-diabetic induced rats, was able to reduce the neuronal damage by increasing SOD and CAT, and reducing MDA and lymphocyte infiltration in nerve tissues [93]. Deguelin also ameliorates diabetic neuropathy, attenuated oxidative stress and neuroinflammation through the activation of NRF2 pathway, and partially restored the conduction velocities of neurons in diabetic rats by increasing $\left(\mathrm{Na}^{+}-\mathrm{K}^{+}\right)$ATPase activity [94]. A similar neuroprotective effect against oxidative stress and inflammation was reported for phloretin, which either alone or in combination with the anti-neuropathic agent duloxetine promoted nerve fiber regeneration in STZ-induced diabetic rats [95].

A study performed to assess the role of resveratrol in diabetic neuropathy showed that it provides neuroprotection by increasing SOD and reducing GSH and inhibiting nitrosative stress and myeloperoxidase (MPO) activity in diabetic rats [96]. Likewise, quercetin in combination with moderate exercise training attenuated neuropathy and restored histological alterations in sciatic 
nerves in STZ-diabetic rats through antioxidant enzyme induction and down-regulation of free radical production [97]. In vitro experiments revealed that inhibition of NF-KB and activation of NRF2/Heme-oxygenase-1 (HO-1) signaling pathways contribute to the anti-inflammatory and antioxidant effects of quercetin, cinnamaldehyde and hirudin in dorsal root ganglion neurons exposed to high glucose $[98,99]$. Similarly, puerarin inhibited oxidative stress and apoptosis induced by hyperglycemia in Schwann cells via suppression of caspase-3 cascade [100].

\subsection{Diabetic Macrovascular Complications}

Macrovascular manifestations of diabetes include primarily diseases of the coronary and peripheral arteries, leading to cardiovascular events. Early macrovascular disease is associated with atherosclerotic plaque in the vessels that supply blood to the heart, brain, limbs, and other organs, whereas late stages of macrovascular disease involve complete arterial obstruction whit an increased risk of myocardial infarction and stroke [15].

It is well known that DM increases cardiovascular morbidity and mortality. However, surprisingly in the last years, the role of flavonoids on cardiovascular complications associated with DM has been poorly studied compared to other diabetic complications such as retinopathy or nephropathy. Most of the studies are focused on assessing the role of flavonoids on endothelial dysfunction since it is one of the earliest and most prevalent abnormalities of cardiovascular complications associated with DM [101].

Bharat et al. tested the possible beneficial effect of blueberry anthocyanins in human aortic endothelial cells exposed to palmitic acid. The authors found that anthocyanins attenuated endothelial dysfunction through the suppression of Nox-mediated ROS production [102]. Rutin also prevented endothelial dysfunction under hyperglycemic conditions both in vitro (human umbilical vein endothelial cells) and in vivo (carbohydrate diet-treated rats), through inhibiting Nox4-mediated ROS generation and NLRP3 inflammasome activation [103].

In a mouse model of T2D, liquiritigenin attenuated cardiac injury through its anti-fibrotic and anti-inflammatory effect by inactivating NF- $\mathrm{kB}$ signaling pathway [104]. Likewise, apigenin protected from cardiovascular damage by preventing cardiomyocyte hypertrophy and fibrosis and attenuating oxidative and inflammatory state in experimental T1D [105].

Resveratrol was able to reduce ROS production in human aortic endothelial cells through the modulation of autophagy as a result of AMPK-mTOR pathway regulation [106] and also exhibited cardioprotective effects in vivo, as it restored the disruption and thickening of the muscle fibers in a diabetic rat model with coronary heart disease [107]. Moreover, resveratrol in combination with glibenclamide was able to reduce ischemia/reperfusion induced arrhythmias in a diabetic rat model [108].

On the other hand, lipid alterations are very common in patients with diabetes, mainly among those who have T2D. It is well known that there is a close relation between hyperlipidemia and the outcome of cardiovascular events in the context of diabetes. Specifically, alterations on the lipid profile can eventually result in atherosclerosis [109]. Therefore, an adequate control of lipid levels is necessary to prevent diabetic complications. Considering the relevance of flavonoids in recent years in the study of diabetes, it is not surprising the existence of numerous studies confirming the anti-hyperlipidemic effect of these compounds. In this sense, a study performed by Mohammed Yusof demonstrated that Hibiscus sabdariffa (roselle) polyphenol-rich extract, including anthocyanidins, acts as a cardioprotective agent by lowering total cholesterol, triglyceride and LDL and increasing HDL [110]. Likewise, isoquercertin [111] and galangin [112] have been shown to decrease triglycerides, phospholipids and free fatty acids in diabetic rats, whereas scutellarin alleviated dyslipidemia in $d b / d b$ mice by increasing HDL and reducing triglycerides and total cholesterol [113].

\section{Clinical Studies on Flavonoids in Diabetes}

In contrast to the extensive experimental research in various models of diabetic complications, a limited number of published clinical studies of flavonoids in diabetic patients are available (Tables 2 and 3). 
Table 2. Summary of the Completed Clinical Trials with Flavonoids for the Treatment of DM.

\begin{tabular}{|c|c|c|c|c|c|}
\hline & Objective to Study & Treatment & Duration & Results & PMID \\
\hline \multirow{6}{*}{ 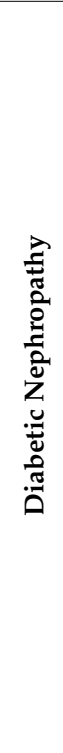 } & $\begin{array}{l}\text { Renoprotective effect of milk thistle } \\
\text { extract on T2D patients with } \\
\text { macroalbuminuria. }\end{array}$ & $\begin{array}{c}n=30 ; 3 \times 140 \mathrm{mg} \text { silymarin } \\
\quad n=30 ; \text { Placebo }\end{array}$ & 3 months & $\begin{array}{l}\text { Significant decrease in UACR levels, urinary TNF- } \alpha \\
\text { and urinary and serum MDA in the silymarin group. }\end{array}$ & $\begin{array}{c}22770926 \\
\text { NCT01003236 }\end{array}$ \\
\hline & $\begin{array}{l}\text { Effect of silymarin on glycemic control } \\
\text { and body mass index in T2D patients } \\
\text { with insulin resistance and poor glycemic } \\
\text { control with oral hypoglycemic agents }\end{array}$ & $\begin{array}{c}n=18 ; 200 \text { mg silymarin }+10 \\
\text { mg Glibenclamide } \\
n=21 ; \text { Placebo }+10 \mathrm{mg} \\
\text { Glibenclamide }\end{array}$ & 4 months & $\begin{array}{l}\text { Silymarin treatment significantly reduced fasting and } \\
\text { postprandial plasma glucose, HbA1c levels and body } \\
\text { mass index. }\end{array}$ & 17887949 \\
\hline & $\begin{array}{l}\text { Effects silymarin administration on the } \\
\text { glycemic state in T2D patients. }\end{array}$ & $\begin{array}{c}n=25 ; 3 \times 200 \mathrm{mg} \text { silymarin } \\
\quad n=26 ; \text { Placebo }\end{array}$ & 4 months & $\begin{array}{l}\text { Decreased significantly FBG, HbA1c, total cholesterol, } \\
\text { LDL, triglyceride, GOT and GPT after treatment with } \\
\text { silymarin. }\end{array}$ & 17072885 \\
\hline & $\begin{array}{l}\text { Safety and effect of green tea } \\
\text { (epigallocatechin gallate, EGCG) in } \\
\text { patients with DN. }\end{array}$ & $\begin{array}{c}n=24 ; \text { ACEi/ARBs }+800 \mathrm{mg} \\
\quad E G C G \\
n=23 ; \text { ACEi/ARBs + Placebo }\end{array}$ & 3 months & $\begin{array}{l}\text { Treatment with green tea extract reduced UACR by } \\
\qquad 41 \% .\end{array}$ & $\begin{array}{c}27320846 \\
\text { NCT01923597 }\end{array}$ \\
\hline & $\begin{array}{l}\text { Effects of isolated soy protein } \\
\text { consumption on urinary albumin } \\
\text { excretion and blood lipid profile in early } \\
\text { stages of DN. }\end{array}$ & $\begin{array}{l}n=14 ; 0.5 \mathrm{~g} / \mathrm{kg} / \text { day of the } \\
\text { dietary protein was provided as } \\
\text { either isolated soy protein }\end{array}$ & $2 \times 8$ weeks & $\begin{array}{l}\text { Soy protein consumption reduced UACR levels by } \\
\qquad 9,55 \% \text {. }\end{array}$ & 15284369 \\
\hline & $\begin{array}{c}\text { Efficacy of curcumin for blocking DN } \\
\text { development in T2D patients (short } \\
\text { time). }\end{array}$ & $n=14 ; 500 \mathrm{mg}$ curcumin & 1 month & $\begin{array}{c}\text { Curcumin attenuated microalbuminuria and reduced } \\
\text { plasma MDA and LPS levels content. Maintaining gut } \\
\text { barrier integrity and function. }\end{array}$ & 25875220 \\
\hline \multirow{3}{*}{ 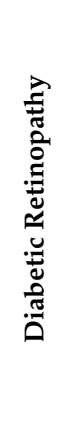 } & $\begin{array}{c}\text { Effects of pycnogenol in early stages of } \\
\text { DR. }\end{array}$ & $\begin{array}{c}n=24 ; 150 \mathrm{mg} \text { pycnogenol } \\
n=22 ; \text { Placebo }\end{array}$ & 2 months & $\begin{array}{l}\text { Visual improvement was subjectively perceived by } 18 \\
\text { of } 24 \text { patients in the pycnogenol group. Significant } \\
\text { improvement visual acuity from baseline. }\end{array}$ & 19916788 \\
\hline & $\begin{array}{l}\text { Evaluate long-term follow-up of the } \\
\text { orally administered combination of } \\
\text { flavonoids for treatment of diabetic } \\
\text { cystoid macular edema without macular } \\
\text { thickening. }\end{array}$ & $\begin{array}{c}n=35 ; 300 \mathrm{mg} \text { Diosmin } \\
15 \mathrm{mg} \text { C. asiatica } \\
160 \mathrm{mg} \text { Melilotus } \\
n=35 ; \text { Placebo }\end{array}$ & 3 years & $\begin{array}{l}\text { Retinal sensitivity reduced in control group only from } \\
\text { month } 6 \text { until month } 36 \text {. In the treatment group, a } \\
\text { greater retinal sensitivity was present at month } 12,24 \text {, } \\
\text { and } 36 .\end{array}$ & 23844756 \\
\hline & $\begin{array}{l}\text { Determine the relationship between } \\
\text { dietary flavonoid-rich fruit and } \\
\text { vegetable consumption on DM-related } \\
\text { biomarkers and DR. }\end{array}$ & $\begin{array}{l}\text { Data from } 381 \text { participants with } \\
\text { DM from the NHANES } \\
\text { 2003-2006. }\end{array}$ & - & $\begin{array}{c}\text { Greater high-flavonoid fruit and vegetable } \\
\text { consumption was associated with lower levels of CRP, } \\
\text { HbA1c and glucose, with reducing the odds of having } \\
\text { diabetic retinopathy by } 30 \% \text {. }\end{array}$ & 25055729 \\
\hline
\end{tabular}


Table 2. Cont.

\begin{tabular}{|c|c|c|c|c|c|}
\hline & Objective to Study & Treatment & Duration & Results & PMID \\
\hline & $\begin{array}{l}\text { Efficacy of anti-oxidant dietary } \\
\text { supplementation reducing the ROS levels } \\
\text { in patients with non-proliferative DR. }\end{array}$ & $\begin{array}{c}n=34 ; 50 \mathrm{mg} \text { pycnogenol, } 30 \mathrm{mg} \\
\text { Vit. E, } 20 \mathrm{mg} \text { CoQ } \\
n=34 ; \text { Placebo }\end{array}$ & $6 \mathrm{M}$ & $\begin{array}{l}\text { In the group receiving antioxidant therapy the levels } \\
\text { of free oxygen radicals and retinal thickness were } \\
\text { significantly reduced over three times. Conversely, in } \\
\text { the control group a significant increase was observed. }\end{array}$ & 25686055 \\
\hline 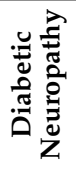 & $\begin{array}{l}\text { Efficacy and safety of QR-333 (quercetin, } \\
\text { ascorbyl palmitate and vitamin D3) in } \\
\text { the treatment of diabetic neuropathy. }\end{array}$ & $\begin{array}{l}n=23 \text {; three topical } \\
\text { applications QR-333 } \\
n=11 ; \text { Placebo }\end{array}$ & $1 \mathrm{M}$ & $\begin{array}{c}\text { QR-333 produced significant relief of some symptoms } \\
\text { of diabetic neuropathy and was safe and well } \\
\text { tolerated. }\end{array}$ & $\begin{array}{c}16112498 \\
\text { NCT16112498 }\end{array}$ \\
\hline \multirow{6}{*}{ 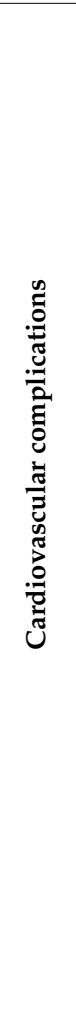 } & $\begin{array}{l}\text { Effect of flavanol-rich chocolate in } \\
\text { patients with hypertension. }\end{array}$ & $\begin{array}{c}n=20 \text {; Cross-over } \\
100 \mathrm{mg} \text { Dark Chocolate } \\
\text { (88 mg flavanols) } \\
90 \mathrm{mg} \text { flavanol-free White } \\
\text { Chocolate }\end{array}$ & $\begin{array}{l}15 \mathrm{~d} \text { per } \\
\text { treatment }\end{array}$ & $\begin{array}{l}\text { Dark chocolate decreased blood pressure and serum } \\
\text { LDL cholesterol, improved FMD, and ameliorated } \\
\text { insulin sensitivity in hypertensive patients. }\end{array}$ & 16027246 \\
\hline & $\begin{array}{c}\text { Evaluate whether regular ingestion of an } \\
\text { unsweetened, strongly defatted and } \\
\text { flavanol-rich cocoa powder might } \\
\text { improve BP and glucose and lipid } \\
\text { metabolism in stably treated T2D } \\
\text { subjects. }\end{array}$ & $\begin{array}{c}n=17 \text {; Five } \times 0.5 \mathrm{~g} \text { cocoa powder } \\
\text { capsules } \\
n=18 ; \text { Placebo }\end{array}$ & $3 \mathrm{M}$ & $\begin{array}{l}\text { Daily intake of } 2.5 \mathrm{~g} \text { of flavanol-rich, unsweetened } \\
\text { and strongly defatted cocoa powder does not affect BP, } \\
\text { glucose and lipid metabolism in stably-treated } \\
\text { patients with T2D and hypertension in a fasting state. }\end{array}$ & 30301127 \\
\hline & $\begin{array}{c}\text { Effect of dietary flavonoids on CVD risk } \\
\text { in postmenopausal women with T2D on } \\
\text { established statin and hypoglycemic } \\
\text { therapy. }\end{array}$ & \multirow{2}{*}{$\begin{array}{c}n=59 ; 27 \text { g flavonoid-enriched } \\
\text { chocolate } \\
\text { n= 59; Placebo }\end{array}$} & \multirow{2}{*}{$12 \mathrm{M}$} & $\begin{array}{l}\text { Improvement in insulin sensitivity was observed. } \\
\text { Reductions in total cholesterol, HDL-cholesterol ratio } \\
\text { and LDL cholesterol. Estimated } 10 \text { year total coronary } \\
\text { heart disease risk was attenuated after flavonoid } \\
\text { intervention. }\end{array}$ & \multirow{2}{*}{$\begin{array}{c}22250063 \\
\text { NCT00677599 }\end{array}$} \\
\hline & $\begin{array}{l}\text { Effect of combined isoflavone and } \\
\text { flavan-3-ol intake on vascular function in } \\
\text { postmenopausal women with T2D. }\end{array}$ & & & $\begin{array}{l}\text { The flavonoid intervention did not significantly } \\
\text { change the intima-media thickness of the common } \\
\text { carotid artery, augmentation index, or BP, but pulse } \\
\text { pressure variability improved. }\end{array}$ & \\
\hline & $\begin{array}{l}\text { Effect of oral Hesperidin } \\
\text { supplementation in hemodynamic } \\
\text { changes in T2D patients. }\end{array}$ & $\begin{array}{c}n=32 ; 500 \mathrm{mg} \text { Hesperidin } \\
\quad n=32 ; \text { Placebo }\end{array}$ & $1.5 \mathrm{M}$ & $\begin{array}{l}\text { Significant difference in mean percent change of SBP, } \\
\text { diastolic blood pressure, mean arterial BP, serum TAC, } \\
\text { and inflammatory markers between Hesperidin and } \\
\text { control groups. }\end{array}$ & 29468764 \\
\hline & $\begin{array}{l}\text { Association between the intake of total } \\
\text { polyphenols and polyphenol classes with } \\
\text { the major CV risk factors in a T2D } \\
\text { population. TOSCA.IT study. }\end{array}$ & $n=2573$ people with T2D & 10 years & $\begin{array}{l}\text { A diet characterized by a higher intake of total } \\
\text { polyphenols was associated with a better } \\
\text { cardiovascular risk factors profile and a lower grade } \\
\text { of subclinical inflammation. }\end{array}$ & $\begin{array}{c}27890487 \\
\text { NCT00700856 }\end{array}$ \\
\hline
\end{tabular}


Table 3. Ongoing Clinical Trials of Flavonoids, Flavonoid-Rich Foods and Flavonoid-Rich Dietary Patterns Intervention in DM.

\begin{tabular}{|c|c|c|c|c|c|}
\hline Title & Design & Objective & Patients & Treatment & Duration \\
\hline $\begin{array}{l}\text { Green tea extract on Soluble } \\
\text { RAGE in Patients with DN } \\
\text { (NCT03622762) }\end{array}$ & $\begin{array}{l}\text { Double blind, randomized } \\
\text { and placebo controlled }\end{array}$ & $\begin{array}{l}\text { Evaluate effect of administration of green } \\
\text { tea extract on soluble RAGE and renal } \\
\text { damage in patients with T2D. }\end{array}$ & $\begin{array}{c}30 \\
\text { patients }\end{array}$ & $\begin{array}{l}\text { Twice daily: } \\
400 \text { mg green tea extract } \\
\text { vs. } 400 \mathrm{mg} \text { placebo }\end{array}$ & 3 months \\
\hline $\begin{array}{l}\text { Inflammation and Stem Cells in } \\
\text { Diabetic and CKD } \\
\text { (NCT03325322) }\end{array}$ & Randomized, parallel & $\begin{array}{l}\text { Study the efficacy of fisetin on } \\
\text { stem/stromal cell function, kidney } \\
\text { function, inflammation and physical } \\
\text { activity in advanced CKD patients. }\end{array}$ & $\begin{array}{c}30 \\
\text { patients }\end{array}$ & $\begin{array}{l}\text { Fisetin } 20 \mathrm{mg} / \mathrm{kg} / \text { day, } \\
\text { orally for } 2 \text { consecutive } \\
\text { days vs. placebo }\end{array}$ & 1 year \\
\hline $\begin{array}{l}\text { Randomized controlled study } \\
\text { to evaluate the efficacy and } \\
\text { safety of WH-1 ointment for the } \\
\text { treatment of chronic diabetic } \\
\text { foot ulcers } \\
\text { (NCT01898923) }\end{array}$ & $\begin{array}{l}\text { Randomized, evaluator } \\
\text { blinded, active-controlled, } \\
\text { multicentric }\end{array}$ & $\begin{array}{c}\text { Evaluate efficacy and safety of } \mathrm{WH}-1 \\
\text { ointment compared to Aquacel } \\
\text { hydrofiber dressing. }\end{array}$ & 236 patients & $\begin{array}{l}\text { WH-1 ointment }(1,25 \%) \\
\text { twice daily for up to } 16 \\
\text { weeks vs. Aquacel } \\
\text { hydrofiber dressings } \\
\text { changed daily, on } \\
\text { alternate days or three } \\
\text { times a week }\end{array}$ & 4 months \\
\hline $\begin{array}{c}\text { Metabolic Benefits of Drinking } \\
\text { Blueberry Tea in T2D } \\
\text { (NCT02629952) }\end{array}$ & $\begin{array}{l}\text { Open, randomized, } \\
\text { crossover assigned. }\end{array}$ & $\begin{array}{c}\text { Determine whether chronic consumption } \\
\text { of blueberry tea improve metabolic and } \\
\text { vascular health in people with and } \\
\text { without T2D. }\end{array}$ & $\begin{array}{c}36 \\
\text { patients }\end{array}$ & $\begin{array}{l}\text { Three cups of blueberry } \\
\text { tea per day vs. non } \\
\text { treatment }\end{array}$ & 1 month \\
\hline $\begin{array}{c}\text { Effects of Mediterranean Diet } \\
\text { Intervention in Diabetic Heart } \\
\text { Disease } \\
\text { (NCT03757845) }\end{array}$ & $\begin{array}{l}\text { Randomized, parallel, } \\
\text { double-blind }\end{array}$ & $\begin{array}{l}\text { Examine short-term effects of modified } \\
\text { Mediterranean diet on lipogenic } \\
\text { signaling pathway in T2D patients. }\end{array}$ & $\begin{array}{c}48 \\
\text { patients }\end{array}$ & $\begin{array}{l}\text { Mediterranean diet vs. } \\
\text { control diet }\end{array}$ & 9 days \\
\hline
\end{tabular}




\subsection{Diabetic Nephropathy}

Several studies have provided evidence supporting a beneficial effect of flavonoids, flavonoid-rich foods and polyphenolic natural product on DN. To date, the main bioactive phytochemicals assayed in clinical trials on DN are: silymarin, green tea extract, soy protein and curcumin. Fallahzadeh et al. [114] evaluated the renoprotective effect of silymarin, an isomeric mixture of seven flavonolignans present in milk thistle, in a randomized controlled double-blind trial in 60 patients with type $2 \mathrm{DN}$ and macroalbuminuria (urinary albumin excretion $>300 \mathrm{mg} / 24 \mathrm{~h}$ ). Administration of three daily tablets (140 mg of silymarin each) for 3 months reduced urinary albumin-creatinine ratio (UACR), urinary levels of TNF- $\alpha$ and urinary and serum levels of MDA. Silymarin also demonstrated to improve the glycemic profile (reducing fasting blood glucose and $\mathrm{HbA1c}$ ) when administered to diabetic patients in addition to the standard treatment (hypoglycemic agent) $[115,116]$.

Borges et al. [117] also evaluated the impact of green tea extract (epigallocatechin gallate) on the UACR in T1D and T2D patients. Administration of four daily capsules of $200 \mathrm{mg}$ of epigallocatechin gallate to 24 patients for 3 months resulted in a significant decrease in UACR ( $41 \%$ of baseline). These results are in accordance with the results obtained by Teixeira [118] and Yang [119], who also observed a decrease in the UACR levels through administration of flavonoids in T2D patients. A later study performed by Sattarinezhad [120] also showed a decrease in the UACR when administering resveratrol. A meta-analysis performed by Liu et al. [121] showed the potential renal protective effects of breviscapine (flavonoid of Erigeron breviscapus) injections, reducing urine protein, serum creatinine and blood urea nitrogen in DN patients. Despite the progress in the flavonoids nephroprotection research, further studies in larger cohorts, longer follow-up and more robust endpoints (e.g., glomerular filtration rate and disease progression) are needed to assess the use of flavonoids as an add-on therapy to current standard of care in DN.

\subsection{Diabetic Retinopathy}

The therapeutic role of flavonoids in DR has been evaluated in several clinical trials using mainly pycnogenol and diosmin. Steigerwalt et al. [122] evaluated in 46 T2D patients with well controlled blood glucose $(\mathrm{HbA} 1 \mathrm{c}<7 \%)$ and early stages of DR the efficacy of pycnogenol to improve microcirculation, retinal edema, and visual acuity. Subjects were daily treated with $3 \times 50 \mathrm{mg}$ pycnogenol or placebo tablets for 2 months. Visual improvement was perceived in 18 of 24 patients in the pycnogenol group and visual acuity significantly improved in the treated group. It was concluded that pycnogenol taken at early stages of retinopathy may enhance retinal blood circulation accompanied by regression of edema, which favorably improves patient vision. Forte et al. [123] evaluated, in 70 T2D patients with diabetic cystoid macular edema (CME) without macular thickening, the long-term effects of an oral pill containing $300 \mathrm{mg}$ of Diosmin, $15 \mathrm{mg}$ of Centella asiatica and $160 \mathrm{mg}$ of Melilotus. They concluded that oral administration of this combination provided preservation of retinal sensitivity during the 36 months of follow up, when compared with untreated patients. Mahoney et al. [124] evaluated the influence of dietary flavonoids in data of 381 diabetic patients from the National Health and Nutrition Examination Survey (NHANES from 2003 to 2006). C-reactive protein, HbA1C, fasting glucose and insulin were measured in blood samples and a retinal imaging exam was done to assess DR. A high-flavonoid fruit and vegetable consumption index was created from a food frequency questionnaire and it was concluded that diabetic adults had lower degrees of inflammation, better glycemic control, and reduced odds of diabetic retinopathy when consuming more flavonoids in the diet. Domanico et al. [125] evaluated the changes in circulating levels of ROS and central macular thickening in 68 patients with non-proliferative diabetic nephropathy. One daily tablet containing $50 \mathrm{mg}$ of pycnogenol, $30 \mathrm{mg}$ of vitamin $\mathrm{E}$ and $20 \mathrm{mg}$ of coenzyme $\mathrm{Q}_{10}$ was administered for 6 months and the blood levels of ROS were determined using the free oxygen radical test. A significant decrease in the free radical levels of the patients receiving the anti-oxidant therapy was observed, whereas a significant increase occurred in the control group. The central macular thickening was significantly reduced in the treated group, whereas no significant changes were found in the control group. A review made by 
Zhang et al. [126], analyzed studies published up to June 2018 that evaluated the effectiveness and safety of single herbal medicine in DR. They included randomized controlled trials and quasi-randomized trials that investigated the effects of any single herb (or extracts from a single herb) as a treatment for people with DR. The authors could not draw conclusions about the effect of any single herb or herbal extract on DR from the current available evidence due to the lack of placebo control group. Therefore, further adequately designed trials are needed to establish the evidence.

\subsection{Diabetic Neuropathy}

In diabetic neuropathy, the only flavonoids that have been studied are quercetin and puerarin. Valensi et al. [127] evaluated in a proof-of-concept study the effect of a topical compound containing quercetin in 34 patients. The primary objective was to decrease the oxidative stress that contributes to peripheral diabetic neuropathy and thus to alleviate the symptoms. The compound appeared to have certain effects, offering relief of diabetic neuropathy symptoms and improving quality of life. Subsequently, they performed a bigger trial [127], where this effect was further studied, but no results were published. Wu et al. [128] made a systematic review and meta-analysis of randomized controlled trials involving efficacy and safety of puerarin injection in treatment of diabetic peripheral neuropathy. The authors included 22 low-quality studies involving 1664 participants. Puerarin was effective and safe for the treatment of diabetic peripheral neuropathy. However, since the articles included in the study were not of high-quality, more studies should be conducted to strengthen their findings. Zheng et al. [129] reviewed the therapeutic efficacy of combined therapy of diabetic peripheral neuropathy with breviscapine and mecobalamine, an endogenous coenzyme B12. They analyzed 17 studies with a total of 1398 patients including 718 treated with breviscapine and mecobalamin and 680 treated with mecobalamin alone. In these studies, patients received diet control, physical exercise, and glucose-lowering therapy before interventions. This meta-analysis suggests that the combined therapy is safe and effective for these patients, although more high-quality, controlled, randomized clinical trials are needed for further confirmation.

\subsection{Cardiovascular Complications}

Early research [130,131] provided some evidence that cocoa products, which have a high content of flavonoids, may contribute to cardiovascular protection. Accordingly, a recent review by Ried et al. [132] afforded evidence for the blood pressure-lowering effect of flavanol-rich chocolate and cocoa products. Dicks et al. investigated whether regular ingestion of $2.5 \mathrm{~g} /$ day of flavanol-rich cocoa powder, in addition to their standard medication, might affect blood pressure as well as glucose and lipid metabolism in 42 stable treated subjects with T2D. They did not see any improvement in cardiometabolic parameters and attributed this finding to the fact that antihypertensive medication and cocoa flavonols could modulate partly the same targets. Therefore, they outlined the need of new studies focusing on the preventive effect of cocoa against diabetes and other cardiometabolic diseases in individuals with preexisting abnormalities that do not require any pharmacological treatment. Curtis et al. [133-135] evaluated the effect of 1 year therapy with flavonoids, in addition to statin-therapy, on cardiovascular risk reduction in postmenopausal women with T2D, and concluded that long-term flavan-3-ol and isoflavone intakes may improve markers of arterial stiffness and aspects of hemodynamic function in T2D patients taking established medication. However, additional studies are required to confirm this theory. Homayouni et al. [136] carried out a clinical trial on 64 T2D patients to study the blood pressure lowering and anti-inflammatory effects of Hesperidin ( $500 \mathrm{mg} /$ day) administered for 6 weeks. Data on blood pressure and anti-inflammatory markers was recorded. The hesperidin group, but not the control group, had a significant reduction in systolic blood pressure and mean arterial blood pressure after the intervention period and the level of IL- 6 and TNF- $\alpha$ were significantly reduced. The Thiazolidinediones Or Sulfonylureas Cardiovascular Accidents Intervention Trial (TOSCA.IT) study analyzed the dietary habits of 2573 participants with T2D [137]. Anthropometric measures, plasma lipids, blood pressure, $\mathrm{C}$-reactive protein and $\mathrm{HbA} 1 \mathrm{c}$ levels were measured. It was concluded that a diet characterized by a 
higher intake of total polyphenols was associated with a better cardiovascular risk factors profile and a lower grade of subclinical inflammation.

\section{Ongoing Clinical Trials}

A search in clinicaltrials.gov and in the AdisInsight database was done to analyze ongoing clinical trials related with Flavonoids and Diabetes. Only five trials were found (Table 3). Among them, the only diabetic complication approached was DN.

One of the studies [138] will evaluate the effects of green tea extract on RAGEs in T2D patients with DN. Thirty patients will receive $400 \mathrm{mg}$ of tea extract or placebo twice a day during 12 weeks and soluble RAGEs and renal damage will be evaluated through the measure of the following parameters: soluble RAGE concentration, glomerular filtration rate, albumin/creatinine ratio, fasting plasma glucose, $\mathrm{Hb} 1 \mathrm{Ac}$ concentration, systolic and diastolic arterial pressure, alanine aminotransferase, aspartate aminotransferase, total cholesterol, triglycerides, HDL-cholesterol, LDL-cholesterol, weight and visceral fat. Another study [139] evaluates the efficacy of fisetin on stem cells in 30 patients with diabetic kidney disease. Fisetin will be administered for two consecutive days vs. placebo and the efficacy on adipose tissue-derived mesenchymal stem/stromal cell function, kidney function (eGFR, UACR), markers of inflammation (C-reactive protein), and physical function in individuals with advanced chronic kidney disease will be tested. Other study is also evaluating the role of flavonoids on diabetic foot ulcers [140]. Furthermore, a 4 week interventional study is planned to evaluate the metabolic benefits of drinking three daily cups of blueberry tea in 36 T2D patients [141]. Also, a study to evaluate the effects of Mediterranean diet before coronary artery by-pass grafting surgery [142] is going to be performed on 48 patients with T2D.

There are also two observational studies planned [143,144], with a follow-up period higher than 10 years, that will study the appearance of different clinical conditions, for example DM and metabolic syndrome, and try to correlate them with their risk factors. In brief, although there are some ongoing clinical trials, there is still a lack of trials targeted to investigate the possible beneficial effect of different therapeutic strategies based on flavonoids in diabetic complications. Moreover, there are some clinically unexplored diabetic complications where flavonoids could be beneficial.

\section{Toxicity and Adverse Effects of Flavonoids}

Although most flavonoids, flavonoid-rich foods, flavonoid-rich dietary patterns and phenolic compounds are considered safe, there have been studies of toxic flavonoid-drugs interactions, liver failure, contact dermatitis, hemolytic anemia and estrogenic-related concerns, among others [145]. In this regard, Alkhalidy et al. mentioned some studies where flavonoids, in the presence of copper, may become pro-oxidant as well as the potential mutagenicity of quercetin after long-term intake [51]. The authors also suggest that flavonoids should not be given in large quantities until their biological and potential adverse effects are clarified. The studies of Bugel et al., using a zebrafish embryo-larval toxicity bioassay, also showed adverse effects on early embryogenesis of some flavonoids and flavonoid-like chemicals [146]. Therefore, the potential harmful effects of certain flavonoids should be considered by pharmaceutical companies at the time of preclinical validation both in vitro and in vivo.

One of the major problems of bringing flavonoids to the market is, in general, its poor availability. This information has been gathered mainly with flavonoids contained in many foods. Due to the great variability of flavonoids and phenolic compounds, each of them should be evaluated when planning its development for clinical use. Among the different strategies designed with the aim of optimizing the solubility and bioavailability of flavonoids, novel strategies are needed $[147,148]$. In this regard, the application of flavonoids through nanoparticles and nanodelivery has been considered in DM [149].

\section{Future Perspectives and Conclusions}

This comprehensive review addresses, from an objective point of view, the current state of the art about the preclinical and clinical use of flavonoids in tissue-specific manifestations of DM. As from the 
year 2000, the number of published studies regarding the therapeutic application of flavonoids has been exponential. There is extensive evidence of the anti-diabetic effects of flavonoids, mainly based on the local modulation of the inflammatory, oxidative and lipotoxic microenvironment leading to a protective effect in the tissue and organs affected by DM (Figure 3).

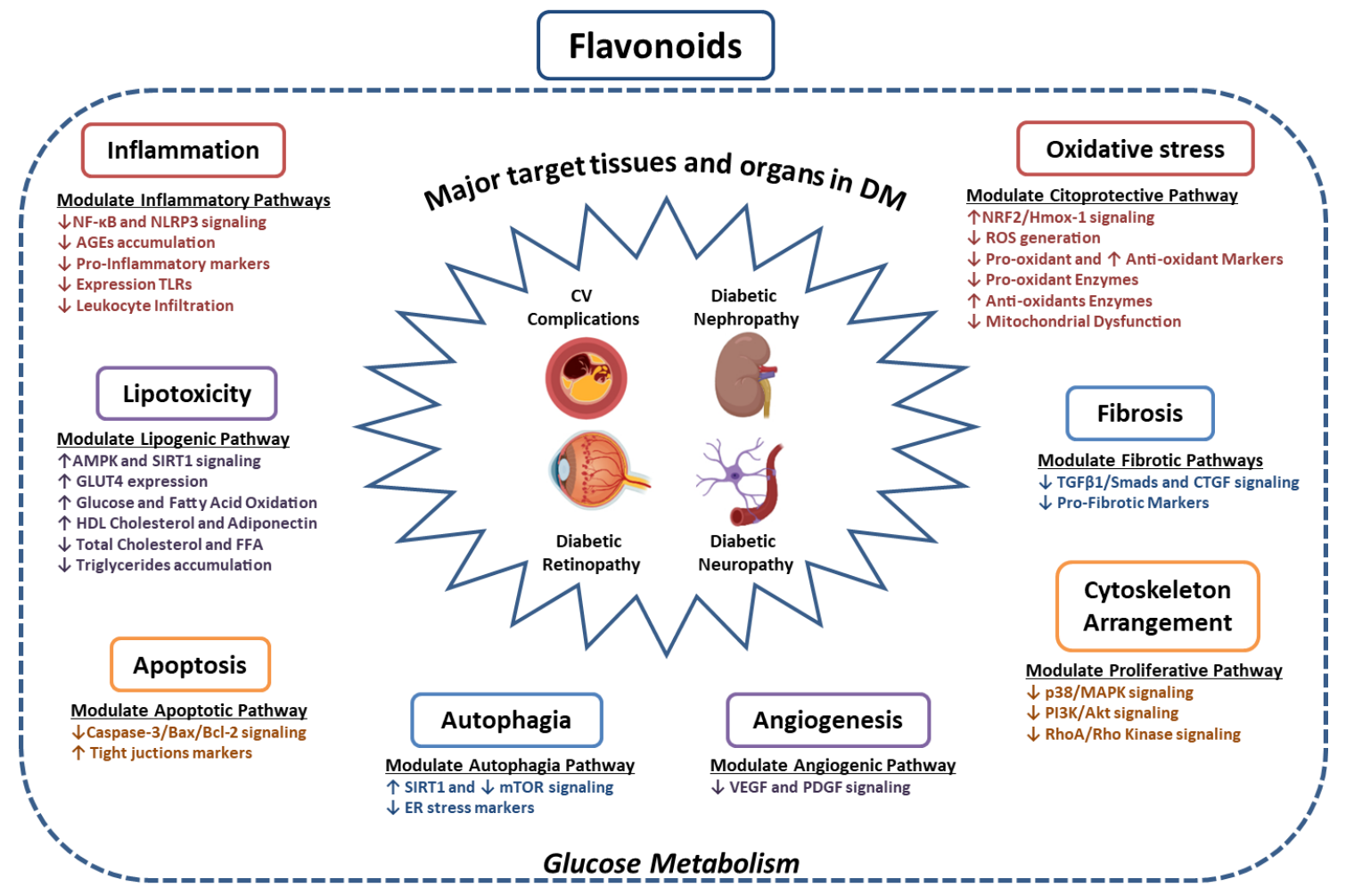

Figure 3. Potential beneficial effects of flavonoids in specific target organ of DM complications. AGEs, advanced glication end products; AMPK, activated protein kinase; Bax, Bcl-2 associated X; Bcl-2; B-cell lymphoma 2; CTGF, connective tissue growth factor; FFA, free fatty acid; GLUT4, glucose transporter type 4; HDL Cholesterol, High Density Lipoprotein Cholesterol; Hmox-1, Heme oxygenase (decycling) 1; MAPK, mitogen-activated protein kinases; mTOR, mammalian Target of Rapamycin; NF-K $\beta$, Nuclear factor kappa beta; NRF2, Nuclear Factor Erythroid 2-related Factor 2; PDGF, Platelet Derived Growth Factor; Rho, Ras homologous; RhoA, Ras homolog family member A; ROS, reactive oxygen species; SIRT1, sirtuin 1; TGF $\beta 1$, transforming growth factor beta 1; TLRs, toll like receptors; VEGF, vascular endothelial growth factor.

DM is a current global epidemic disease and, despite the fact that current therapies have facilitated a better control of the disease, few are the therapies aiming to regulate local inflammatory and oxidative stress. Potentially, the introduction of nutraceuticals into clinical practice could have an added value in reducing or retarding the micro or macrovascular complications associated with DM and therefore the direct and indirect health costs devoted to these patients. One of the great difficulties described for the clinical application of flavonoids refers to the low scientific evidence regarding the in vivo biodistribution and pharmacokinetic parameters of these compounds. Additionally, because the complications of DM are characterized by a slow and insidious development, the preclinical assessment of its therapeutic effects becomes even more complex.

The current technological development in the pharmaceutical industry predicts a promising future of the use of flavonoids in inflammatory based diseases, increasing the purity percentage of compounds, optimizing their formulation in order to obtain greater stabilization in vivo and target tissue bioavailability, thus prolonging their therapeutic effect. 
In brief, we provide updated information concerning the discrepancy between the numerous experimental studies supporting the efficacy of flavonoids on diabetic complications and the lack of appropriate and well-designed clinical trials. Due to the well-described beneficial effects on different mechanisms involved in diabetic complications, the excellent tolerability and low cost, future randomized controlled studies with compounds that have adequate bioavailability should be evaluated as add-on therapy on well-established anti-diabetic drugs.

Author Contributions: All authors have contributed to the writing, editing, discussion and revision of this manuscript, and have approved the final version. All authors have read and agreed to the published version of the manuscript.

Funding: This paper was not funded. The authors work has been supported by FEDER-ISCIII Funds (PI17/00130, PI17/01495), Spanish Ministry of Economy and Competitiveness (RTI2018-098788-B-100, DTS17/00203, DTS19/00093, RYC-2017-22369), Spanish Society of Cardiology (SEC), Spanish Society of Nephrology (SEN) and Spanish Society of Atherosclerosis (SEA). TCO is an employee of FAES Pharma. The authors (except JAM) have an ongoing research project in common with FAES Pharma on Flavonoids in diabetic complications under the auspices of the joint-RETOS Collaborations Project 2017 (RTC-2017-6089-1), program supported by Spanish Ministry of Economy and Competitiveness. No other relevant affiliations or financial involvement with any organization or entity with a financial interest in or financial conflict with the subject matter or materials discussed in the manuscript. This includes employment, consultancies, honoraria, stock ownership or options, expert testimony, grants or patents received or pending, or royalties.

Conflicts of Interest: The authors declare no conflict of interest. The funders had no role in the design of the study; in the collection, analyses, or interpretation of data; in the writing of the manuscript, or in the decision to publish the results.

\section{Abbreviations}

$\alpha$-SMA, alpha-smooth muscle actin; ACE, angiotensin converting enzyme; BDNF, brain-derived neurotrophic factor; CAT, catalase; Col I, collagen I; Col II, collagen II; Col IV, collagen IV; eNOS, endothelial nitric oxide synthase; ER, endoplasmic reticulum; FFA, free fatty acids; FGF-23, fibroblast growth factor 23; GPx, glutathione peroxidase; GSH, glutathione; HFI, High fructose induce model; HG, high glucose; HO-1 Heme oxygenase 1; HPE, H. sabdariffa (roselle) polyphenol-rich extract; IBA1, ionized calcium-binding adapter molecule 1; ICAM-1, Intercellular Adhesion Molecule 1 IL-6, interleukin 6; IL-18, interleukin 18; LC3-II, LC3-phosphatidylethanolamine conjugate; LRAT, lecithin retinol acyltransferase; MAPK, mitogen-activated protein kinases; MDA, malondialdehyde; MPO, myeloperoxidase; NF- $\kappa \beta$, nuclear factor $\kappa \beta$; NOX4, NADPH oxidase 4; Nrf2, nuclear factor erythroid 2-related factor 2; PEDF, and pigment epithelium-derived factor; PI3K, phosphoinositide 3-kinase; PPL, phospholipids; RDH5, retinol dehydrogenase 5; ROS, reactive oxygen species; RPE65, retinal pigment epithelium-specific $65 \mathrm{kDa}$ protein; SIRT1, sirtuin 1; SOD, superoxide dismutase; T2D, type 2 diabetes; T1D, type 1 diabetes; TG, triglycerides; TGF- $\beta 1$, transforming growth factor beta 1 ; TNF $\alpha$, tumor necrosis factor alpha; VEGF, vascular endothelial growth factor.

\section{References}

1. International Diabetes Federation. Eighth Edition. Lancet 2017, 388, 1659-1724. [CrossRef]

2. Beagley, J.; Guariguata, L.; Weil, C.; Motala, A.A. Global estimates of undiagnosed diabetes in adults. Diabetes Res. Clin. Pract. 2014, 103, 150-160. [CrossRef]

3. Currie, C.J.; Poole, C.D.; Evans, M.; Peters, J.R.; Morgan, C.L. Mortality and other important diabetes-related outcomes with insulin vs other antihyperglycemic therapies in type 2 diabetes. J. Clin. Endocrinol. Metab. 2013, 98, 668-677. [CrossRef]

4. Dall, T.M.; Yang, W.; Gillespie, K.; Mocarski, M.; Byrne, E.; Cintina, I.; Beronja, K.; Semilla, A.P.; Iacobucci, W.; Hogan, P.F. The Economic Burden of Elevated Blood Glucose Levels in 2017: Diagnosed and Undiagnosed Diabetes, Gestational Diabetes Mellitus, and Prediabetes. Diabetes Care 2019, 42, 1661-1668. [CrossRef]

5. Fioretto, P.; Bruseghin, M.; Berto, I.; Gallina, P.; Manzato, E.; Mussap, M. Renal protection in diabetes: role of glycemic control. J. Am. Soc. Nephrol. JASN 2006, 17, S86-S89. [CrossRef]

6. Cho, N.H.; Shaw, J.E.; Karuranga, S.; Huang, Y.; da Rocha Fernandes, J.D.; Ohlrogge, A.W.; Malanda, B. IDF Diabetes Atlas: Global estimates of diabetes prevalence for 2017 and projections for 2045. Diabetes Res. Clin. Pract. 2018, 138, 271-281. [CrossRef]

7. Gregg, E.W.; Li, Y.; Wang, J.; Burrows, N.R.; Ali, M.K.; Rolka, D.; Williams, D.E.; Geiss, L. Changes in diabetes-related complications in the United States, 1990-2010. N. Engl. J. Med. 2014, 370, 1514-1523. [CrossRef] 
8. Kern, M.; Kloting, N.; Mark, M.; Mayoux, E.; Klein, T.; Bluher, M. The SGLT2 inhibitor empagliflozin improves insulin sensitivity in $\mathrm{db} / \mathrm{db}$ mice both as monotherapy and in combination with linagliptin. Metab. Clin. Exp. 2016, 65, 114-123. [CrossRef]

9. Gnudi, L.; Coward, R.J.M.; Long, D.A. Diabetic Nephropathy: Perspective on Novel Molecular Mechanisms. Trends Endocrinol. Metab. TEM 2016, 27, 820-830. [CrossRef]

10. Tanaka, S.; Sugiura, Y.; Saito, H.; Sugahara, M.; Higashijima, Y.; Yamaguchi, J.; Inagi, R.; Suematsu, M.; Nangaku, M.; Tanaka, T. Sodium-glucose cotransporter 2 inhibition normalizes glucose metabolism and suppresses oxidative stress in the kidneys of diabetic mice. Kidney Int. 2018, 94, 912-925. [CrossRef]

11. Nolen-Doerr, E.; Stockman, M.C.; Rizo, I. Mechanism of Glucagon-Like Peptide 1 Improvements in Type 2 Diabetes Mellitus and Obesity. Curr. Obes. Rep. 2019, 8, 284-291. [CrossRef]

12. Sedeek, M.; Montezano, A.C.; Hebert, R.L.; Gray, S.P.; Di Marco, E.; Jha, J.C.; Cooper, M.E.; Jandeleit-Dahm, K.; Schiffrin, E.L.; Wilkinson-Berka, J.L.; et al. Oxidative stress, Nox isoforms and complications of diabetespotential targets for novel therapies. J. Cardiovasc. Transl. Res. 2012, 5, 509-518. [CrossRef]

13. Forbes, J.M.; Cooper, M.E. Mechanisms of diabetic complications. Physiol. Rev. 2013, 93, 137-188. [CrossRef]

14. Barrett, E.J.; Liu, Z.; Khamaisi, M.; King, G.L.; Klein, R.; Klein, B.E.K.; Hughes, T.M.; Craft, S.; Freedman, B.I.; Bowden, D.W.; et al. Diabetic Microvascular Disease: An Endocrine Society Scientific Statement. J. Clin. Endocrinol. Metab. 2017, 102, 4343-4410. [CrossRef]

15. Fowler, M.J. Microvascular and macrovascular complications of diabetes. Clin. Diabetes. 2011, $29,116-122$. [CrossRef]

16. IDF Diabetes Atlas, 9th edition 2019. Available online: https://www.diabetesatlas.org (accessed on 3 February 2020).

17. Cerf, M.E. Beta cell dysfunction and insulin resistance. Front. Endocrinol. 2013, 4, 37. [CrossRef]

18. Sandholm, N.; Salem, R.M.; McKnight, A.J.; Brennan, E.P.; Forsblom, C.; Isakova, T.; McKay, G.J.; Williams, W.W.; Sadlier, D.M.; Makinen, V.P.; et al. New susceptibility loci associated with kidney disease in type 1 diabetes. PLoS Genetics 2012, 8, e1002921. [CrossRef]

19. Ahlqvist, E.; van Zuydam, N.R.; Groop, L.C.; McCarthy, M.I. The genetics of diabetic complications. Nat. Rev. Nephrol. 2015, 11, 277-287. [CrossRef]

20. Mueller, P.W.; Rogus, J.J.; Cleary, P.A.; Zhao, Y.; Smiles, A.M.; Steffes, M.W.; Bucksa, J.; Gibson, T.B.; Cordovado, S.K.; Krolewski, A.S.; et al. Genetics of Kidneys in Diabetes (GoKinD) study: a genetics collection available for identifying genetic susceptibility factors for diabetic nephropathy in type 1 diabetes. J. Am. Soc. Nephrol. JASN 2006, 17, 1782-1790. [CrossRef]

21. Chang, Y.C.; Chang, E.Y.; Chuang, L.M. Recent progress in the genetics of diabetic microvascular complications. World J. Diabetes 2015, 6, 715-725. [CrossRef]

22. Van Zuydam, N.R.; Ahlqvist, E.; Sandholm, N.; Deshmukh, H.; Rayner, N.W.; Abdalla, M.; Ladenvall, C.; Ziemek, D.; Fauman, E.; Robertson, N.R.; et al. A Genome-Wide Association Study of Diabetic Kidney Disease in Subjects With Type 2 Diabetes. Diabetes 2018, 67, 1414-1427. [CrossRef]

23. Anders, H.J.; Huber, T.B.; Isermann, B.; Schiffer, M. CKD in diabetes: diabetic kidney disease versus nondiabetic kidney disease. Nat.Rev. Nephrol. 2018, 14, 361-377. [CrossRef]

24. Obrosova, I.G.; Kador, P.F. Aldose reductase / polyol inhibitors for diabetic retinopathy. Curr. Pharm. Biotechnol. 2011, 12, 373-385. [CrossRef]

25. Jenkins, A.J.; Joglekar, M.V.; Hardikar, A.A.; Keech, A.C.; O’Neal, D.N.; Januszewski, A.S. Biomarkers in Diabetic Retinopathy. Rev. Diabetic Stud. RDS 2015, 12, 159-195. [CrossRef]

26. Veron, D.; Reidy, K.J.; Bertuccio, C.; Teichman, J.; Villegas, G.; Jimenez, J.; Shen, W.; Kopp, J.B.; Thomas, D.B.; Tufro, A. Overexpression of VEGF-A in podocytes of adult mice causes glomerular disease. Kidney Int. 2010, 77, 989-999. [CrossRef]

27. Zoja, C.; Benigni, A.; Remuzzi, G. The Nrf2 pathway in the progression of renal disease. Nephrol. Dial. Transpl. Off. Pub. Eur. Dial. Transpl. Assoc. Eur. Renal Assoc. 2014, 29 (Suppl. 1), i19-i24. [CrossRef]

28. Tan, S.M.; de Haan, J.B. Combating oxidative stress in diabetic complications with Nrf2 activators: how much is too much? Redox Rep. Commun. Free Radic. Res. 2014, 19, 107-117. [CrossRef]

29. Uruno, A.; Yagishita, Y.; Yamamoto, M. The Keap1-Nrf2 system and diabetes mellitus. Arch. Biochem. Biophys. 2015, 566, 76-84. [CrossRef] 
30. Cheng, H.; Harris, R.C. Renal endothelial dysfunction in diabetic nephropathy. Cardiovasc. Hematol. Disord. Drug Targ. 2014, 14, 22-33. [CrossRef]

31. Capellini, V.K.; Celotto, A.C.; Baldo, C.F.; Olivon, V.C.; Viaro, F.; Rodrigues, A.J.; Evora, P.R. Diabetes and vascular disease: basic concepts of nitric oxide physiology, endothelial dysfunction, oxidative stress and therapeutic possibilities. Curr. Vasc. Pharm. 2010, 8, 526-544. [CrossRef] [PubMed]

32. Santiago, A.R.; Boia, R.; Aires, I.D.; Ambrosio, A.F.; Fernandes, R. Sweet Stress: Coping With Vascular Dysfunction in Diabetic Retinopathy. Front. Physiol. 2018, 9, 820. [CrossRef] [PubMed]

33. Lindblom, R.; Higgins, G.; Coughlan, M.; de Haan, J.B. Targeting Mitochondria and Reactive Oxygen Species-Driven Pathogenesis in Diabetic Nephropathy. Rev. Diabetic Stud. RDS 2015, 12, 134-156. [CrossRef]

34. Miranda-Diaz, A.G.; Pazarin-Villasenor, L.; Yanowsky-Escatell, F.G.; Andrade-Sierra, J. Oxidative Stress in Diabetic Nephropathy with Early Chronic Kidney Disease. J. Diabetes Res. 2016, 2016, 7047238. [CrossRef]

35. Santilli, F.; Cipollone, F.; Mezzetti, A.; Chiarelli, F. The role of nitric oxide in the development of diabetic angiopathy. Hormone and Metabolic Research = Hormon- und Stoffwechselforschung = Hormones et metabolisme 2004, 36, 319-335. [CrossRef]

36. Shikata, K.; Makino, H. Microinflammation in the pathogenesis of diabetic nephropathy. J. Diabetes Invest. 2013, 4, 142-149. [CrossRef]

37. Moreno, J.A.; Gomez-Guerrero, C.; Mas, S.; Sanz, A.B.; Lorenzo, O.; Ruiz-Ortega, M.; Opazo, L.; Mezzano, S.; Egido, J. Targeting inflammation in diabetic nephropathy: a tale of hope. Expert Opin. Invest. Drugs 2018, 27, 917-930. [CrossRef]

38. Tesch, G.H. Diabetic nephropathy-Is this an immune disorder? Clin. Sci. 2017, 131, 2183-2199. [CrossRef]

39. Qiu, A.W.; Liu, Q.H.; Wang, J.L. Blocking IL-17A Alleviates Diabetic Retinopathy in Rodents. Cell. Physiol. Biochem. Int. J. Exp. Cell. Physiol. Biochem. Pharmacol. 2017, 41, 960-972. [CrossRef]

40. Garibotto, G.; Carta, A.; Picciotto, D.; Viazzi, F.; Verzola, D. Toll-like receptor-4 signaling mediates inflammation and tissue injury in diabetic nephropathy. J. Nephrol. 2017, 30, 719-727. [CrossRef]

41. Elmarakby, A.A.; Sullivan, J.C. Relationship between oxidative stress and inflammatory cytokines in diabetic nephropathy. Cardiovasc. Ther. 2012, 30, 49-59. [CrossRef]

42. Vinayagam, R.; Xu, B. Antidiabetic properties of dietary flavonoids: a cellular mechanism review. Nutr. Metab. 2015, 12, 60. [CrossRef]

43. Santos-Buelga, C.; Feliciano, A.S. Flavonoids: From Structure to Health Issues. Molecules 2017, 22. [CrossRef]

44. Testa, R.; Bonfigli, A.R.; Genovese, S.; De Nigris, V.; Ceriello, A. The Possible Role of Flavonoids in the Prevention of Diabetic Complications. Nutrients 2016, 8. [CrossRef]

45. Panche, A.N.; Diwan, A.D.; Chandra, S.R. Flavonoids: an overview. J. Nutr. Sci. 2016, 5, e47. [CrossRef]

46. Zhang, S.; Wang, J.; Zhao, H.; Luo, Y. Effects of three flavonoids from an ancient traditional Chinese medicine Radix puerariae on geriatric diseases. Brain Circ. 2018, 4, 174-184. [CrossRef]

47. CIMA. Available online: https://cima.aemps.es (accessed on 24 May 2019).

48. Al-Ishaq, R.K.; Abotaleb, M.; Kubatka, P.; Kajo, K.; Busselberg, D. Flavonoids and Their Anti-Diabetic Effects: Cellular Mechanisms and Effects to Improve Blood Sugar Levels. Biomolecules 2019, 9. [CrossRef]

49. Burton-Freeman, B.; Brzezinski, M.; Park, E.; Sandhu, A.; Xiao, D.; Edirisinghe, I. A Selective Role of Dietary Anthocyanins and Flavan-3-ols in Reducing the Risk of Type 2 Diabetes Mellitus: A Review of Recent Evidence. Nutrients 2019, 11. [CrossRef]

50. Ghorbani, A.; Rashidi, R.; Shafiee-Nick, R. Flavonoids for preserving pancreatic beta cell survival and function: A mechanistic review. Biomedicine Pharmacotherapy = Biomedecine E pharmacotherapie 2019, 111, 947-957. [CrossRef]

51. Alkhalidy, H.; Wang, Y.; Liu, D. Dietary Flavonoids in the Prevention of T2D: An Overview. Nutrients 2018, 10. [CrossRef]

52. Eid, H.M.; Haddad, P.S. The Antidiabetic Potential of Quercetin: Underlying Mechanisms. Curr. Med. Chem. 2017, 24, 355-364. [CrossRef]

53. Prasad, C.N.; Anjana, T.; Banerji, A.; Gopalakrishnapillai, A. Gallic acid induces GLUT4 translocation and glucose uptake activity in 3T3-L1 cells. FEBS letters 2010, 584, 531-536. [CrossRef]

54. Yamashita, Y.; Kishida, H.; Nakagawa, K.; Yoshioka, Y.; Ashida, H. Liquorice flavonoid oil suppresses hyperglycaemia accompanied by skeletal muscle myocellular GLUT4 recruitment to the plasma membrane in KK-A(y) mice. Int. J. Food Sci. Nutr. 2019, 70, 294-302. [CrossRef] 
55. Wang, T.; Jiang, H.; Cao, S.; Chen, Q.; Cui, M.; Wang, Z.; Li, D.; Zhou, J.; Wang, T.; Qiu, F.; et al. Baicalin and its metabolites suppresses gluconeogenesis through activation of AMPK or AKT in insulin resistant HepG-2 cells. Eur. J. Med. Chem. 2017, 141, 92-100. [CrossRef]

56. Li, X.; Chen, Y.; Shen, J.Z.; Pan, Q.; Yang, W.; Yan, H.; Liu, H.; Ai, W.; Liao, W.; Guo, S. Epigallocatechin Gallate Inhibits Hepatic Glucose Production in Primary Hepatocytes via Downregulating PKA Signaling Pathways and Transcriptional Factor FoxO1. J. Agricult. Food Chem. 2019, 67, 3651-3661. [CrossRef]

57. Yadollah, S.; Kazemipour, N.; Bakhtiyari, S.; Nazifi, S. Palmitate-induced insulin resistance is attenuated by Pioglitazone and EGCG through reducing the gluconeogenic key enzymes expression in HepG2 cells. J. Med. Life 2017, 10, 244-249.

58. Lima-Fontes, M.; Costa, R.; Rodrigues, I.; Soares, R. Xanthohumol Restores Hepatic Glucolipid Metabolism Balance in Type 1 Diabetic Wistar Rats. J. Agricult. Food Chem. 2017, 65, 7433-7439. [CrossRef]

59. Alzaid, F.; Cheung, H.M.; Preedy, V.R.; Sharp, P.A. Regulation of glucose transporter expression in human intestinal Caco-2 cells following exposure to an anthocyanin-rich berry extract. PLoS ONE 2013, 8, e78932. [CrossRef]

60. Kwon, O.; Eck, P.; Chen, S.; Corpe, C.P.; Lee, J.H.; Kruhlak, M.; Levine, M. Inhibition of the intestinal glucose transporter GLUT2 by flavonoids. FASEB J. 2007, 21, 366-377. [CrossRef]

61. Kim, S.H.; Jo, S.H.; Kwon, Y.I.; Hwang, J.K. Effects of onion (Allium cepa L.) extract administration on intestinal alpha-glucosidases activities and spikes in postprandial blood glucose levels in SD rats model. Int. J. Mol. Sci. 2011, 12, 3757-3769. [CrossRef]

62. Jayachandran, M.; Vinayagam, R.; Ambati, R.R.; Xu, B.; Chung, S.S.M. Guava Leaf Extract Diminishes Hyperglycemia and Oxidative Stress, Prevents beta-Cell Death, Inhibits Inflammation, and Regulates NF-kB Signaling Pathway in STZ Induced Diabetic Rats. BioMed Res. Int. 2018, 2018, 4601649. [CrossRef]

63. Lim, Y.J.; Kim, J.H.; Pan, J.H.; Kim, J.K.; Park, T.S.; Kim, Y.J.; Lee, J.H.; Kim, J.H. Naringin Protects Pancreatic beta-Cells Against Oxidative Stress-Induced Apoptosis by Inhibiting Both Intrinsic and Extrinsic Pathways in Insulin-Deficient Diabetic Mice. Mol. Nutr. Food Res. 2018, 62. [CrossRef]

64. Wang, L.P.; Gao, Y.Z.; Song, B.; Yu, G.; Chen, H.; Zhang, Z.W.; Yan, C.F.; Pan, Y.L.; Yu, X.Y. MicroRNAs in the Progress of Diabetic Nephropathy: A Systematic Review and Meta-Analysis. Evid. Based Complement. Altern. Med. eCAM 2019, 2019, 3513179. [CrossRef]

65. Pichler, R.; Afkarian, M.; Dieter, B.P.; Tuttle, K.R. Immunity and inflammation in diabetic kidney disease: translating mechanisms to biomarkers and treatment targets. Am. J. Physiol. Renal Physiol. 2017, 312, F716-F731. [CrossRef]

66. Jiang, Y.; Liu, J.; Zhou, Z.; Liu, K.; Liu, C. Diosmetin Attenuates Akt Signaling Pathway by Modulating Nuclear Factor Kappa-Light-Chain-Enhancer of Activated B Cells (NF-kappaB)/Inducible Nitric Oxide Synthase (iNOS) in Streptozotocin (STZ)-Induced Diabetic Nephropathy Mice. Med. Sci. Monitor Int. Med. J. Exp. Clin. Res. 2018, 24, 7007-7014. [CrossRef]

67. Liu, X.L.; Liu, W.P.; Wang, L.L.; Feng, L. Effects of flavonoids from Pyrrosiae folium on pathological changes and inflammatory response of diabetic nephropathy. Zhongguo Zhong yao za zhi = Zhongguo zhongyao zazhi= China J. Chin. Mater. Med. 2018, 43, 2352-2357. [CrossRef]

68. Wang, K.J.; Zhao, J.L. Corn silk (Zea mays L.), a source of natural antioxidants with alpha-amylase, alpha-glucosidase, advanced glycation and diabetic nephropathy inhibitory activities. Biomed. Pharmacother. Biomed. Pharmacother. 2019, 110, 510-517. [CrossRef]

69. Zhu, X.; Shi, J.; Li, H. Liquiritigenin attenuates high glucose-induced mesangial matrix accumulation, oxidative stress, and inflammation by suppression of the NF-kappaB and NLRP3 inflammasome pathways. Biomed. Pharmacother. Biomed. Pharmacother. 2018, 106, 976-982. [CrossRef]

70. Chen, F.; Wei, G.; Xu, J.; Ma, X.; Wang, Q. Naringin ameliorates the high glucose-induced rat mesangial cell inflammatory reaction by modulating the NLRP3 Inflammasome. BMC Complement. Altern. Med. 2018, 18, 192. [CrossRef]

71. Kashihara, N.; Haruna, Y.; Kondeti, V.K.; Kanwar, Y.S. Oxidative stress in diabetic nephropathy. Curr. Med. Chem. 2010, 17, 4256-4269. [CrossRef]

72. Bloch-Damti, A.; Bashan, N. Proposed mechanisms for the induction of insulin resistance by oxidative stress. Antioxid. Redox Signal. 2005, 7, 1553-1567. [CrossRef] 
73. Oza, M.J.; Kulkarni, Y.A. Formononetin attenuates kidney damage in type 2 diabetic rats. Life Sci. 2019, 219, 109-121. [CrossRef]

74. Zhang, J.; Yang, S.; Li, H.; Chen, F.; Shi, J. Naringin ameliorates diabetic nephropathy by inhibiting NADPH oxidase 4. Eur. J. Pharm. 2017, 804, 1-6. [CrossRef]

75. Jiang, W.; Wang, R.; Liu, D.; Zuo, M.; Zhao, C.; Zhang, T.; Li, W. Protective Effects of Kaempferitrin on Advanced Glycation End Products Induce Mesangial Cell Apoptosis and Oxidative Stress. Int. J. Mol. Sci. 2018, 19. [CrossRef]

76. Fukami, K.; Yamagishi, S.; Ueda, S.; Okuda, S. Role of AGEs in diabetic nephropathy. Curr. Pharm. Des. 2008, 14, 946-952. [CrossRef]

77. Lee, E.J.; Kang, M.K.; Kim, D.Y.; Kim, Y.H.; Oh, H.; Kang, Y.H. Chrysin Inhibits Advanced Glycation End Products-Induced Kidney Fibrosis in Renal Mesangial Cells and Diabetic Kidneys. Nutrients 2018, 10. [CrossRef]

78. Al-Hussaini, H.; Kilarkaje, N. Trans-resveratrol mitigates type 1 diabetes-induced oxidative DNA damage and accumulation of advanced glycation end products in glomeruli and tubules of rat kidneys. Toxicol. Appl. Pharm. 2018, 339, 97-109. [CrossRef]

79. Semeraro, F.; Morescalchi, F.; Cancarini, A.; Russo, A.; Rezzola, S.; Costagliola, C. Diabetic retinopathy, a vascular and inflammatory disease: Therapeutic implications. Diabetes Metab. 2019. [CrossRef]

80. Wang, W.; Zhang, Y.; Jin, W.; Xing, Y.; Yang, A. Catechin Weakens Diabetic Retinopathy by Inhibiting the Expression of NF-kappaB Signaling Pathway-Mediated Inflammatory Factors. Ann. Clin. Lab. Sci. 2018, 48, 594-600.

81. Mehrabadi, M.E.; Salemi, Z.; Babaie, S.; Panahi, M. Effect of Biochanin A on Retina Levels of Vascular Endothelial Growth Factor, Tumor Necrosis Factor-Alpha and Interleukin-1Beta in Rats With Streptozotocin-Induced Diabetes. Can. J. Diab. 2018, 42, 639-644. [CrossRef]

82. Mahmoud, A.M.; Abd El-Twab, S.M.; Abdel-Reheim, E.S. Consumption of polyphenol-rich Morus alba leaves extract attenuates early diabetic retinopathy: the underlying mechanism. Eur. J. Nutr. 2017, 56, 1671-1684. [CrossRef] [PubMed]

83. Al-Dosari, D.I.; Ahmed, M.M.; Al-Rejaie, S.S.; Alhomida, A.S.; Ola, M.S. Flavonoid Naringenin Attenuates Oxidative Stress, Apoptosis and Improves Neurotrophic Effects in the Diabetic Rat Retina. Nutrients 2017, 9. [CrossRef] [PubMed]

84. Zhang, T.; Mei, X.; Ouyang, H.; Lu, B.; Yu, Z.; Wang, Z.; Ji, L. Natural flavonoid galangin alleviates microglia-trigged blood-retinal barrier dysfunction during the development of diabetic retinopathy. J. Nutr. Biochem. 2019, 65, 1-14. [CrossRef]

85. Huang, W.; Yan, Z.; Li, D.; Ma, Y.; Zhou, J.; Sui, Z. Antioxidant and Anti-Inflammatory Effects of Blueberry Anthocyanins on High Glucose-Induced Human Retinal Capillary Endothelial Cells. Oxid. Med. Cel. Long. 2018, 2018, 1862462. [CrossRef] [PubMed]

86. Arumugam, B.; Palanisamy, U.D.; Chua, K.H.; Kuppusamy, U.R. Protective effect of myricetin derivatives from Syzygium malaccense against hydrogen peroxide-induced stress in ARPE-19 cells. Mol. Vis. 2019, 25, 47-59. [PubMed]

87. Lv, P.; Yu, J.; Xu, X.; Lu, T.; Xu, F. Eriodictyol inhibits high glucose-induced oxidative stress and inflammation in retinal ganglial cells. J. Cell. Biochem. 2019, 120, 5644-5651. [CrossRef] [PubMed]

88. Dai, C.; Jiang, S.; Chu, C.; Xin, M.; Song, X.; Zhao, B. Baicalin protects human retinal pigment epithelial cell lines against high glucose-induced cell injury by up-regulation of microRNA-145. Exp. Mol. Pathol. 2019, 106, 123-130. [CrossRef]

89. Kang, M.K.; Lee, E.J.; Kim, Y.H.; Kim, D.Y.; Oh, H.; Kim, S.I.; Kang, Y.H. Chrysin Ameliorates Malfunction of Retinoid Visual Cycle through Blocking Activation of AGE-RAGE-ER Stress in Glucose-Stimulated Retinal Pigment Epithelial Cells and Diabetic Eyes. Nutrients 2018, 10. [CrossRef]

90. Pop-Busui, R.; Boulton, A.J.; Feldman, E.L.; Bril, V.; Freeman, R.; Malik, R.A.; Sosenko, J.M.; Ziegler, D. Diabetic Neuropathy: A Position Statement by the American Diabetes Association. Diabetes Care 2017, 40, 136-154. [CrossRef]

91. Vincent, A.M.; Brownlee, M.; Russell, J.W. Oxidative stress and programmed cell death in diabetic neuropathy. Ann. N. Y. Acad.Sci. 2002, 959, 368-383. [CrossRef] 
92. Schmidt, R.E. Neuropathology and pathogenesis of diabetic autonomic neuropathy. Int. Rev. Neurobiol. 2002, 50, 257-292. [CrossRef] [PubMed]

93. Addepalli, V.; Suryavanshi, S.V. Catechin attenuates diabetic autonomic neuropathy in streptozotocin induced diabetic rats. Biomed. Pharmacother. Biomed. Pharmacother. 2018, 108, 1517-1523. [CrossRef] [PubMed]

94. Chen, J.; Liu, W.; Yi, H.; Hu, X.; Peng, L.; Yang, F. The Natural Rotenoid Deguelin Ameliorates Diabetic Neuropathy by Decreasing Oxidative Stress and Plasma Glucose Levels in Rats via the Nrf2 Signalling Pathway. Cell. Physiol. Biochem. Int. J. Exp. Cell. Physiol. Biochem. Pharmacol. 2018, 48, 1164-1176. [CrossRef] [PubMed]

95. Balaha, M.; Kandeel, S.; Kabel, A. Phloretin either alone or in combination with duloxetine alleviates the STZ-induced diabetic neuropathy in rats. Biomed. Pharmacother. Biomed. Pharmacother. 2018, 101, 821-832. [CrossRef]

96. Ferreira, P.E.B.; Beraldi, E.J.; Borges, S.C.; Natali, M.R.M.; Buttow, N.C. Resveratrol promotes neuroprotection and attenuates oxidative and nitrosative stress in the small intestine in diabetic rats. Biomed. Pharmacother. Biomed. Pharmacother. 2018, 105, 724-733. [CrossRef]

97. Chis, I.C.; Clichici, A.; Nagy, A.L.; Oros, A.; Catoi, C.; Clichici, S. Quercetin in association with moderate exercise training attenuates injuries induced by experimental diabetes in sciatic nerves. J. Physiol. Pharmacol. 2017, 68, 877-886.

98. Shi, Y.; Liang, X.C.; Zhang, H.; Sun, Q.; Wu, Q.L.; Qu, L. Combination of quercetin, cinnamaldehyde and hirudin protects rat dorsal root ganglion neurons against high glucose-induced injury through Nrf-2/HO-1 activation and NF-kappaB inhibition. Chin. J. Integr. Med. 2017, 23, 663-671. [CrossRef]

99. Shi, Y.; Liang, X.C.; Zhang, H.; Wu, Q.L.; Qu, L.; Sun, Q. Quercetin protects rat dorsal root ganglion neurons against high glucose-induced injury in vitro through Nrf-2/HO-1 activation and NF-kappaB inhibition. Acta Pharm. Sin. 2013, 34, 1140-1148. [CrossRef]

100. Xue, B.; Wang, L.; Zhang, Z.; Wang, R.; Xia, X.X.; Han, P.P.; Cao, L.J.; Liu, Y.H.; Sun, L.Q. Puerarin may protect against Schwann cell damage induced by glucose fluctuation. J. Nat. Med. 2017, 71, 472-481. [CrossRef]

101. Mozaffarian, D.; Wu, J.H.Y. Flavonoids, Dairy Foods, and Cardiovascular and Metabolic Health: A Review of Emerging Biologic Pathways. Circ. Res. 2018, 122, 369-384. [CrossRef]

102. Bharat, D.; Cavalcanti, R.R.M.; Petersen, C.; Begaye, N.; Cutler, B.R.; Costa, M.M.A.; Ramos, R.; Ferreira, M.R.; Li, Y.; Bharath, L.P.; et al. Blueberry Metabolites Attenuate Lipotoxicity-Induced Endothelial Dysfunction. Mol. Nutr. Food Res. 2018, 62. [CrossRef] [PubMed]

103. Wang, W.; Wu, Q.H.; Sui, Y.; Wang, Y.; Qiu, X. Rutin protects endothelial dysfunction by disturbing Nox4 and ROS-sensitive NLRP3 inflammasome. Biomed. Pharmacother. Biomed. Pharmacother. 2017, 86, 32-40. [CrossRef] [PubMed]

104. Xie, X.W. Liquiritigenin attenuates cardiac injury induced by high fructose-feeding through fibrosis and inflammation suppression. Biomed. Pharmacother. Biomed. Pharmacother. 2017, 86, 694-704. [CrossRef] [PubMed]

105. Liu, H.J.; Fan, Y.L.; Liao, H.H.; Liu, Y.; Chen, S.; Ma, Z.G.; Zhang, N.; Yang, Z.; Deng, W.; Tang, Q.Z. Apigenin alleviates STZ-induced diabetic cardiomyopathy. Mol. Cell. Biochem. 2017, 428, 9-21. [CrossRef] [PubMed]

106. Song, J.; Huang, Y.; Zheng, W.; Yan, J.; Cheng, M.; Zhao, R.; Chen, L.; Hu, C.; Jia, W. Resveratrol reduces intracellular reactive oxygen species levels by inducing autophagy through the AMPK-mTOR pathway. Front. Med. 2018, 12, 697-706. [CrossRef]

107. Huo, X.; Zhang, T.; Meng, Q.; Li, C.; You, B. Resveratrol Effects on a Diabetic Rat Model with Coronary Heart Disease. Med. Sci. Monit. Int. Med. J. Exp. Clin. Res. 2019, 25, 540-546. [CrossRef]

108. Kaya, S.T.; Bozdogan, O.; Ozarslan, T.O.; Taskin, E.; Eksioglu, D.; Erim, F.; Firat, T.; Yasar, S. The protection of resveratrol and its combination with glibenclamide, but not berberine on the diabetic hearts against reperfusion-induced arrhythmias: the role of myocardial KATP channel. Arch. Physiol. Biochem. 2019, 125, 114-121. [CrossRef]

109. Copeland, L.A.; Swendsen, C.S.; Sears, D.M.; MacCarthy, A.A.; McNeal, C.J. Association between triglyceride levels and cardiovascular disease in patients with acute pancreatitis. PLoS ONE 2018, 13, e0179998. [CrossRef]

110. Mohammed Yusof, N.L.; Zainalabidin, S.; Mohd Fauzi, N.; Budin, S.B. Hibiscus sabdariffa (roselle) polyphenol-rich extract averts cardiac functional and structural abnormalities in type 1 diabetic rats. Appl. Physiol. Nutr. Metab. Physiol. Appl. Nutr. Metab. 2018, 43, 1224-1232. [CrossRef] 
111. Jayachandran, M.; Wu, Z.; Ganesan, K.; Khalid, S.; Chung, S.M.; Xu, B. Isoquercetin upregulates antioxidant genes, suppresses inflammatory cytokines and regulates AMPK pathway in streptozotocin-induced diabetic rats. Chem. Biol. Interact. 2019, 303, 62-69. [CrossRef]

112. Aloud, A.A.; Chinnadurai, V.; Govindasamy, C.; Alsaif, M.A.; Al-Numair, K.S. Galangin, a dietary flavonoid, ameliorates hyperglycaemia and lipid abnormalities in rats with streptozotocin-induced hyperglycaemia. Pharm. Biol. 2018, 56, 302-308. [CrossRef] [PubMed]

113. Liu, Y.; Wang, J.; Zhang, X.; Wang, L.; Hao, T.; Cheng, Y.; Wang, D. Scutellarin Exerts Hypoglycemic and Renal Protective Effects in db/db Mice via the Nrf2/HO-1 Signaling Pathway. Oxid. Med. Cell. Long. 2019, 2019, 1354345. [CrossRef] [PubMed]

114. Fallahzadeh, M.K.; Dormanesh, B.; Sagheb, M.M.; Roozbeh, J.; Vessal, G.; Pakfetrat, M.; Daneshbod, Y.; Kamali-Sarvestani, E.; Lankarani, K.B. Effect of addition of silymarin to renin-angiotensin system inhibitors on proteinuria in type 2 diabetic patients with overt nephropathy: a randomized, double-blind, placebo-controlled trial. Am. J. Kidney Dis. 2012, 60, 896-903. [CrossRef] [PubMed]

115. Hussain, S.A. Silymarin as an adjunct to glibenclamide therapy improves long-term and postprandial glycemic control and body mass index in type 2 diabetes. J. Med. Food 2007, 10, 543-547. [CrossRef]

116. Huseini, H.F.; Larijani, B.; Heshmat, R.; Fakhrzadeh, H.; Radjabipour, B.; Toliat, T.; Raza, M. The efficacy of Silybum marianum (L.) Gaertn. (silymarin) in the treatment of type II diabetes: a randomized, double-blind, placebo-controlled, clinical trial. Phytother. Res. PTR 2006, 20, 1036-1039. [CrossRef]

117. Borges, C.M.; Papadimitriou, A.; Duarte, D.A.; Lopes de Faria, J.M.; Lopes de Faria, J.B. The use of green tea polyphenols for treating residual albuminuria in diabetic nephropathy: A double-blind randomised clinical trial. Sci. Rep. 2016, 6, 28282. [CrossRef]

118. Teixeira, S.R.; Tappenden, K.A.; Carson, L.; Jones, R.; Prabhudesai, M.; Marshall, W.P.; Erdman, J.W., Jr. Isolated soy protein consumption reduces urinary albumin excretion and improves the serum lipid profile in men with type 2 diabetes mellitus and nephropathy. J. Nutr. 2004, 134, 1874-1880. [CrossRef]

119. Yang, H.; Xu, W.; Zhou, Z.; Liu, J.; Li, X.; Chen, L.; Weng, J.; Yu, Z. Curcumin attenuates urinary excretion of albumin in type II diabetic patients with enhancing nuclear factor erythroid-derived 2-like 2 (Nrf2) system and repressing inflammatory signaling efficacies. Exp. Clin. Endocrinol. Diabetes 2015, 123, 360-367. [CrossRef]

120. Sattarinezhad, A.; Roozbeh, J.; Shirazi Yeganeh, B.; Omrani, G.R.; Shams, M. Resveratrol reduces albuminuria in diabetic nephropathy: A randomized double-blind placebo-controlled clinical trial. Diabetes Metab. 2019, 45, 53-59. [CrossRef]

121. Liu, X.; Yao, L.; Sun, D.; Zhu, X.; Liu, Q.; Xu, T.; Wang, L. Effect of breviscapine injection on clinical parameters in diabetic nephropathy: A meta-analysis of randomized controlled trials. Exp. Ther. Med. 2016, 12, 1383-1397. [CrossRef]

122. Steigerwalt, R.; Belcaro, G.; Cesarone, M.R.; Di Renzo, A.; Grossi, M.G.; Ricci, A.; Dugall, M.; Cacchio, M.; Schonlau, F. Pycnogenol improves microcirculation, retinal edema, and visual acuity in early diabetic retinopathy. J. Ocul. Pharmacol. Ther. 2009, 25, 537-540. [CrossRef] [PubMed]

123. Forte, R.; Cennamo, G.; Bonavolonta, P.; Pascotto, A.; de Crecchio, G.; Cennamo, G. Long-term follow-up of oral administration of flavonoids, Centella asiatica and Melilotus, for diabetic cystoid macular edema without macular thickening. J. Ocul. Pharmacol. Ther. 2013, 29, 733-737. [CrossRef] [PubMed]

124. Mahoney, S.E.; Loprinzi, P.D. Influence of flavonoid-rich fruit and vegetable intake on diabetic retinopathy and diabetes-related biomarkers. J. Diabetes Complic. 2014, 28, 767-771. [CrossRef] [PubMed]

125. Domanico, D.; Fragiotta, S.; Cutini, A.; Carnevale, C.; Zompatori, L.; Vingolo, E.M. Circulating levels of reactive oxygen species in patients with nonproliferative diabetic retinopathy and the influence of antioxidant supplementation: 6-month follow-up. Indian J. Ophthalmol. 2015, 63, 9-14. [CrossRef]

126. Zhang, H.W.; Zhang, H.; Grant, S.J.; Wan, X.; Li, G. Single herbal medicine for diabetic retinopathy. Cochrane Database Syst. Rev. 2018, 12, CD007939. [CrossRef]

127. Valensi, P.; Le Devehat, C.; Richard, J.L.; Farez, C.; Khodabandehlou, T.; Rosenbloom, R.A.; LeFante, C. A multicenter, double-blind, safety study of QR-333 for the treatment of symptomatic diabetic peripheral neuropathy. A preliminary report. J. Diabetes Complic. 2005, 19, 247-253. [CrossRef]

128. Wu, J.; Zhang, X.; Zhang, B. Efficacy and safety of puerarin injection in treatment of diabetic peripheral neuropathy: a systematic review and meta-analysis of randomized controlled trials. J. Trad. Chin. Med. Chung $i$ tsa chih ying wen pan 2014, 34, 401-410. [CrossRef] 
129. Zheng, C.; Ou, W.; Shen, H.; Zhou, Z.; Wang, J. Combined therapy of diabetic peripheral neuropathy with breviscapine and mecobalamin: a systematic review and a meta-analysis of Chinese studies. BioMed Res. Int. 2015, 2015, 680756. [CrossRef]

130. Grassi, D.; Necozione, S.; Lippi, C.; Croce, G.; Valeri, L.; Pasqualetti, P.; Desideri, G.; Blumberg, J.B.; Ferri, C. Cocoa reduces blood pressure and insulin resistance and improves endothelium-dependent vasodilation in hypertensives. Hypertension 2005, 46, 398-405. [CrossRef]

131. Taubert, D.; Roesen, R.; Lehmann, C.; Jung, N.; Schomig, E. Effects of low habitual cocoa intake on blood pressure and bioactive nitric oxide: a randomized controlled trial. JAMA 2007, 298, 49-60. [CrossRef]

132. Ried, K.; Fakler, P.; Stocks, N.P. Effect of cocoa on blood pressure. Cochrane Database Syst. Rev. 2017, 4, CD008893. [CrossRef] [PubMed]

133. Curtis, P.J.; Sampson, M.; Potter, J.; Dhatariya, K.; Kroon, P.A.; Cassidy, A. Chronic ingestion of flavan-3-ols and isoflavones improves insulin sensitivity and lipoprotein status and attenuates estimated 10-year CVD risk in medicated postmenopausal women with type 2 diabetes: a 1-year, double-blind, randomized, controlled trial. Diabetes Care 2012, 35, 226-232. [CrossRef] [PubMed]

134. Curtis, P.J.; Potter, J.; Kroon, P.A.; Wilson, P.; Dhatariya, K.; Sampson, M.; Cassidy, A. Vascular function and atherosclerosis progression after $1 \mathrm{y}$ of flavonoid intake in statin-treated postmenopausal women with type 2 diabetes: a double-blind randomized controlled trial. Am. J. Clin. Nutr. 2013, 97, 936-942. [CrossRef] [PubMed]

135. The FLAVO Trial: Dietary Flavonoids and Cardiovascular Disease Risk Reduction in Postmenopausal Women With Type 2 Diabetes (FLAVO); Identifier: NCT00677599. Available online: https://clinicaltrials.gov/ ct2/show/NCT00677599 (accessed on 23 December 2019).

136. Homayouni, F.; Haidari, F.; Hedayati, M.; Zakerkish, M.; Ahmadi, K. Blood pressure lowering and anti-inflammatory effects of hesperidin in type 2 diabetes; a randomized double-blind controlled clinical trial. Phytother. Res. PTR 2018, 32, 1073-1079. [CrossRef]

137. Vitale, M.; Vaccaro, O.; Masulli, M.; Bonora, E.; Del Prato, S.; Giorda, C.B.; Nicolucci, A.; Squatrito, S.; Auciello, S.; Babini, A.C.; et al. Polyphenol intake and cardiovascular risk factors in a population with type 2 diabetes: The TOSCA.IT study. Clin. Nutr. 2017, 36, 1686-1692. [CrossRef]

138. Green Tea Extract on Soluble RAGE in Patients With Diabetic Nephropathy. 2019. Identifier: NCT03622762. Available online: https://clinicaltrials.gov/ct2/show/NCT03622762 (accessed on 23 December 2019).

139. Inflammation and Stem Cells in Diabetic and Chronic Kidney Disease. 2019. Identifier: NCT03325322. Available online: https://clinicaltrials.gov/ct2/show/NCT03325322 (accessed on 23 December 2019).

140. Evaluate the Efficacy and Safety of WH-1 Ointment for the Treatment of Chronic Diabetic Foot Ulcers (WH-1). 2019. Identifier: NCT01898923. Available online: https://clinicaltrials.gov/ct2/show/NCT01898923 (accessed on 23 December 2019).

141. Metabolic Benefits of Drinking Blueberry Tea in Type 2 Diabetes. 2019. Identifier: NCT02629952. Available online: https://clinicaltrials.gov/ct2/show/NCT02629952 (accessed on 23 December 2019).

142. Effects of Mediterranean Diet Intervention in Diabetic Heart Disease. Identifier: NCT03757845. Available online: https://clinicaltrials.gov/ct2/show/NCT03757845 (accessed on 23 December 2019).

143. Nanshan Elderly Cohort Study (NECS). 2019; Identifier: NCT03569735. Available online: ClinicalTrials.gov (accessed on 23 December 2019).

144. Guangzhou Nutrition and Health Study (GNHS) (GNHS). 2019; Identifier: NCT03179657. Available online: https:/clinicaltrials.gov/ct2/show/NCT03179657 (accessed on 23 December 2019).

145. Galati, G.; O'Brien, P.J. Potential toxicity of flavonoids and other dietary phenolics: significance for their chemopreventive and anticancer properties. Free Radic. Biol. Med. 2004, 37, 287-303. [CrossRef]

146. Bugel, S.M.; Bonventre, J.A.; Tanguay, R.L. Comparative Developmental Toxicity of Flavonoids Using an Integrative Zebrafish System. Toxicol Sci. 2016, 154, 55-68. [CrossRef]

147. Aiello, P.; Consalvi, S.; Poce, G.; Raguzzini, A.; Toti, E.; Palmery, M.; Biava, M.; Bernardi, M.; Kamal, M.A.; Perry, G.; et al. Dietary flavonoids: Nano delivery and nanoparticles for cancer therapy. Semin Cancer Biol. 2019. [CrossRef] 
148. Bunkar, N.; Shandilya, R.; Bhargava, A.; Samarth, R.M.; Tiwari, R.; Mishra, D.K.; Srivastava, R.K.; Sharma, R.S.; Lohiya, N.K.; Mishra, P.K. Nano-engineered flavonoids for cancer protection. Front. Biosci (Landmark Ed.) 2019, 24, 1097-1157.

149. Hussain, T.; Tan, B.; Murtaza, G.; Liu, G.; Rahu, N.; Saleem Kalhoro, M.; Hussain Kalhoro, D.; Adebowale, T.O.; Usman Mazhar, M.; Rehman, Z.U.; et al. Flavonoids and type 2 diabetes: Evidence of efficacy in clinical and animal studies and delivery strategies to enhance their therapeutic efficacy. Pharmacol. Res. 2020, 152, 104629. [CrossRef]

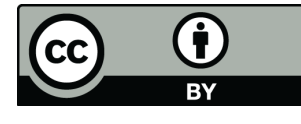

(C) 2020 by the authors. Licensee MDPI, Basel, Switzerland. This article is an open access article distributed under the terms and conditions of the Creative Commons Attribution (CC BY) license (http://creativecommons.org/licenses/by/4.0/). 